\title{
Coniferous wood of Agathoxylon from the La Matilde Formation, (Middle Jurassic), Santa Cruz, Argentina
}

\author{
Adriana C. Kloster, ${ }^{1}$ and Silvia C. Gnaedinger ${ }^{2}$ \\ ${ }^{1}$ Área de Paleontología, Centro de Ecología Aplicada del Litoral, Consejo Nacional de Investigaciones Científicas y Técnicas (CECOAL-CCT \\ CONICET Nordeste-UNNE). 〈klosterdri@gmail.com〉 \\ ${ }^{2}$ Área de Paleontología, Centro de Ecología Aplicada del Litoral, Consejo Nacional de Investigaciones Científicas y Técnicas (CECOAL-CCT \\ CONICET Nordeste-UNNE), Facultad de Ciencias Exactas y Naturales y Agrimensura, Universidad Nacional del Nordeste (FaCENA-UNNE). \\ Casilla de Correo 291, 3400 Corrientes, Argentina, 〈scgnaed@hotmail.com〉
}

\begin{abstract}
In this contribution, four species of Agathoxylon are described from the La Matilde Formation, Gran Bajo de San Julián and central and south-western sectors of Santa Cruz Province, Argentina. Agathoxylon agathioides (Kräusel and Jain) n. comb., Agathoxylon santalense (Sah and Jain) n. comb., Agathoxylon termieri (Attims) Gnaedinger and Herbst, and the new species Agathoxylon santacruzense n. sp. are described based on a detailed description of the secondary xylem. In this work, it was possible to construct scatter plots to elucidate the anatomical differences between the fossil species described on quantitative anatomical data. Comparisons are made with other Agathoxylon species from Gondwana. These parameters can be used to discriminate genera and species of wood found in the same formation, as well as to establish differences/similarities between other taxa described in other formations. Some localities contain innumerable "in situ" petrified trees, which allowed us to infer that these taxa formed small forests, or local forests, or small forests within a dense forest, which is a habitat coincident with the extant Araucariaceae.
\end{abstract}

\section{Introduction}

Sediments of the La Matilde Formation crop out in several areas of Santa Cruz province (Argentina), some localities containing "in situ" silicified trees, with many fallen and fragmented examples (De Barrios et. al., 1999). The geological and paleontological characteristics of the La Matilde Formation have already been described by several authors (e.g., Delhaes, 1913; Frenguelli, 1933; Feruglio, 1949; Stipanicic and Reig, 1957; Spalletti et al., 1982; Panza and Irigoyen, 1995; Panza, 1998).

Sediments of the La Matilde Formation crop out in diverse sectors of the province of Santa Cruz: the central-eastern sector: Cañadón de La Matilde, where the type locality is situated (Criado Roque, 1953; Stipanicic and Reig, 1957; Panza, 1984, 1995, 1998); the central sector, the best known from a paleontological point of view, comprising, among other localities, the "Monumento Natural Bosques Petrificados de Jaramillo" (Jaramillo Petrified Forest National Park) (Panza, 1982, 1995, 1998); the central and south-western sector (Bajo El Puma and estancia Manantial Espejo, among other localities) (Panza, 1986; De Barrios, 1989; Panza and Marín, 1996; Panza and Cobos, 1998); and the Gran Bajo de San Julián sector comprising localities such as Laguna del Molino, Laguna del Carbón, Mina del Gobierno, Mina La Pareja and Puesto Raspuzzi, among others (Panza and De Barrios, 1989; Panza and Irigoyen, 1995).

Herbst et al. (1995) found new outcrops containing large quantities of petrified logs in the Gran Bajo de San Julián sector, which show the same characteristics as those from the north of the province (i.e., forests with in situ petrified trunks and rolled trees). These localities are found in the Estancia El Mineral (Laguna La Guadalosa), Estancia Meseta Chica (Barda Blanca, Cerro Conito, northern part), and Estancia La Silvita (Laguna del Carbón) (Figs. 1, 2).

Anatomical descriptions of Osmundales macrofossils and leaf impressions of the orders Equisetales, Osmundales, Bennettitales, and Coniferales have been made from these outcrops (Feruglio, 1951; Archangelsky and de la Sota, 1962; Herbst, 1977, 2003; Baldoni, 1981, 1990; Herbst and Salazar, 1999). In addition, also from this formation, petrified cones (Spegazzini, 1924; Calder, 1953; Menéndez, 1960; Stockey, 1977, 1978; Stockey and Taylor, 1978), as well as silicified fungi (Singer and Archangelsky, 1957) and wood, Agathoxylon matildense (Zamuner and Falaschi, 2005), have been described from the well-known "Jaramillo Petrified Forests," including areas such as Cerro Madre e Hija and Cerro Cuadrado, among others.

In previous studies of the xyloflora from the Gran Bajo de San Julián sector, taxa of the order Coniferales were described: Protelicoxylon Philippe and Herbstiloxylon Gnaedinger, related to members of the Cupressaceae; Circoporopitys Gnaedinger, two new species of Podocarpoxylon Gothan, and Circoporoxylon Kräusel, belonging to the Podocarpaceae; and Planoxylon Stopes, of the group Protopinaceae. Specimens of Prototaxoxylon Kräusel and Dolianiti of the order Taxales, and Ginkgomyeloxylon tanzanii Giraud and Hankel of the order Ginkgoales, also have been described (Gnaedinger and Herbst, 2006; Gnaedinger, 2007a, b, 2012). 

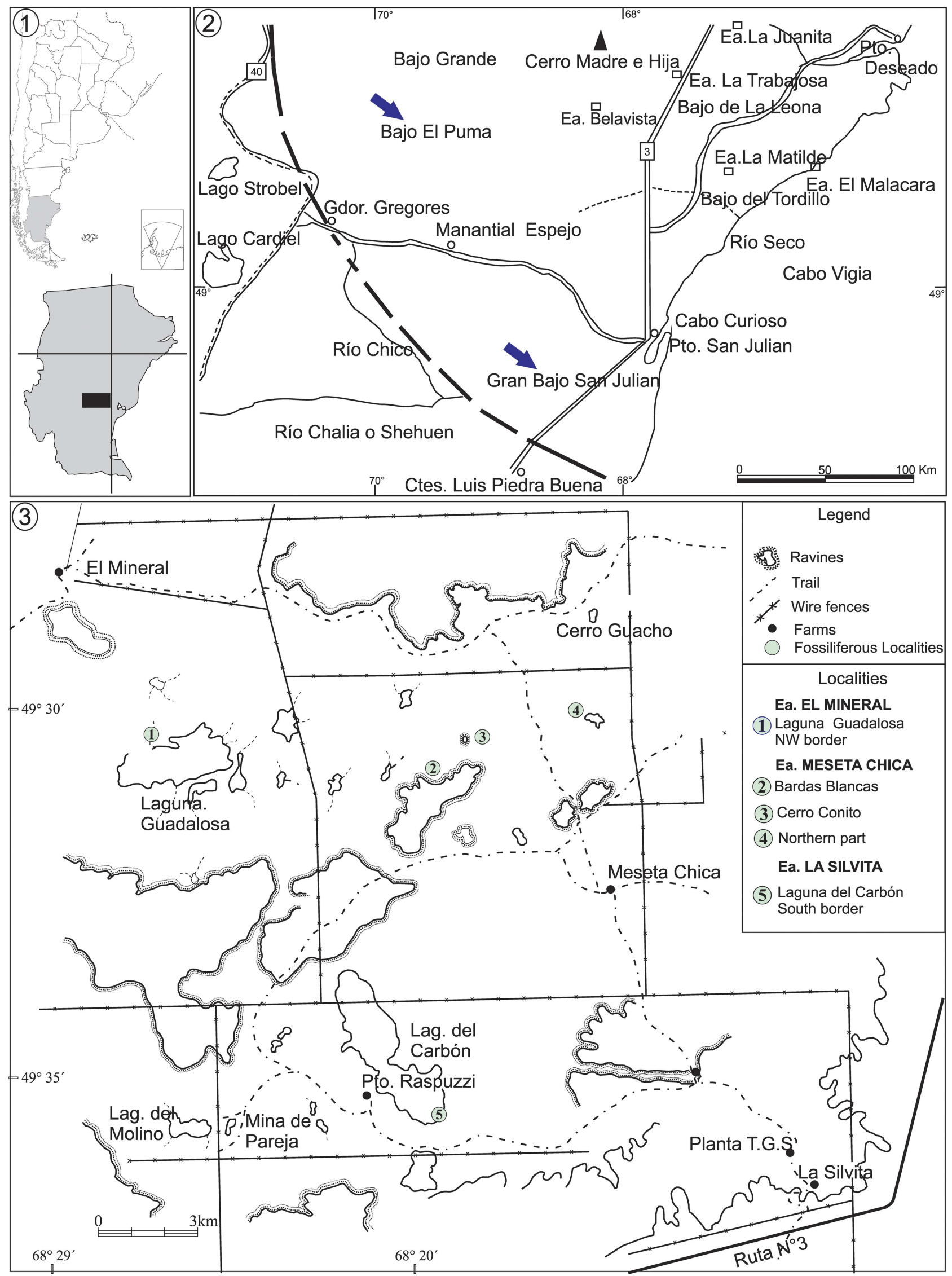

Figure 1. (1) Map showing the location La Matilde Formation of the Santa Cruz Province in Argentina. (2) Map showing the location Bajo El Puma and Gran Bajo San Julián sector (arrows). (3) Geologic map of the Gran Bajo San Julián sector, the circle shows the location of the localities. (Adapted from Gnaedinger and Herbst, 2006). 

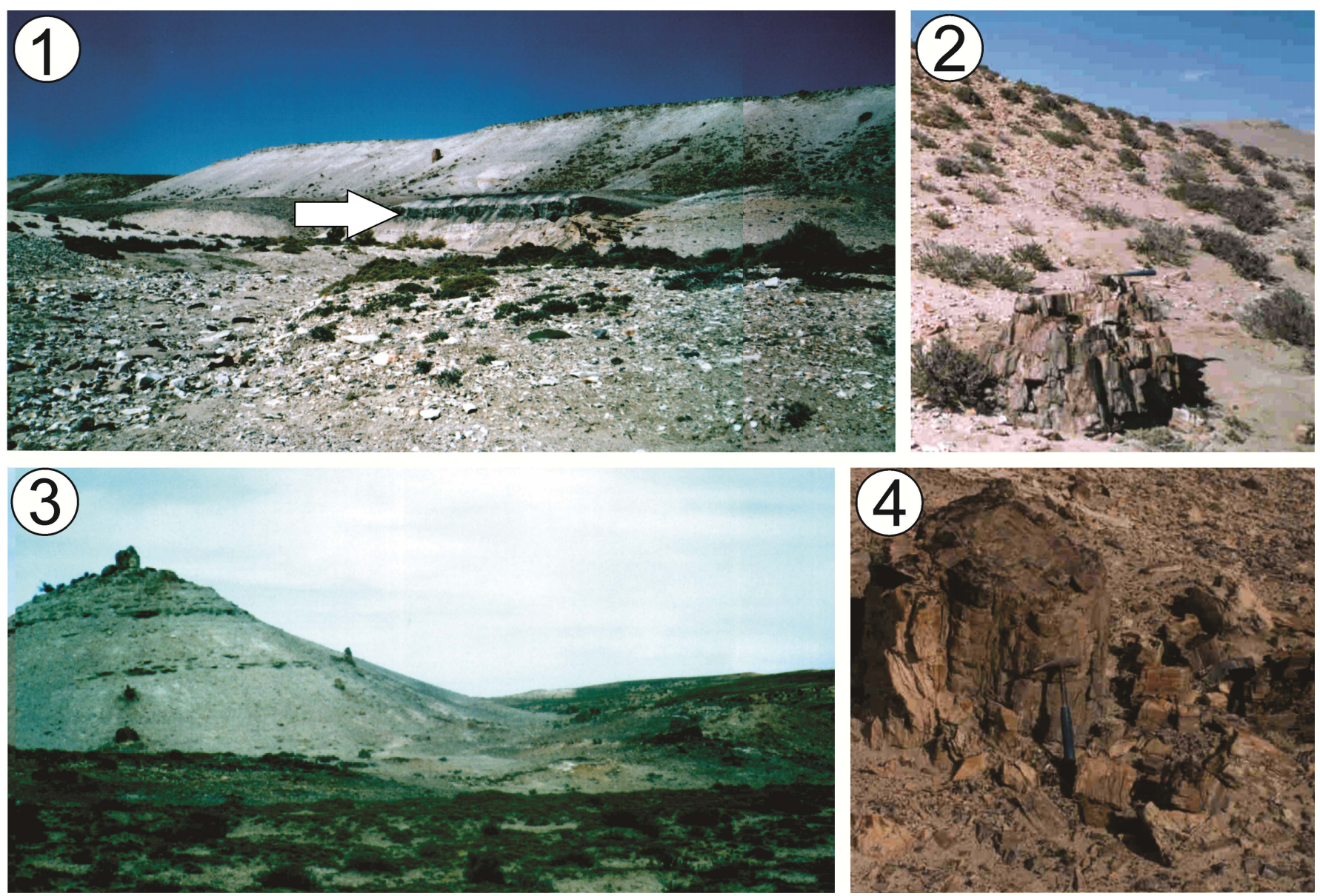

Figure 2. Gran Bajo San Julián localities. (1) Barda Blanca locality showing carbonaceous pelitic levels (arrow); (2) wood "in situ" from Barda Blanca locality; (3) Cerro Conito locality; (4) wood "in situ" from Cerro Conito locality.

In this contribution, Agathoxylon species are described for the first time from the Gran Bajo de San Julián sector (northern part of Estancia Meseta Chica, Barda Blanca, Cerro Conito, Laguna La Guadalosa, and the south-east border of Laguna del Carbón) and the central and south-western sector (Bajo El Puma), collected from the Middle Jurassic of the La Matilde Formation in Argentina.

\section{Geological setting}

The La Matilde Formation is part of the Bahía Laura Group and is widely distributed in the province of Santa Cruz (De Barrios et al., 1999, fig. 28, p. 513) (Fig. 1). The specimens analyzed come from the Gran Bajo San Julián, central, and south-western areas (Fig. 1.2). In the Gran Bajo San Julián sector, the La Matilde Formation comprises $\sim 70-80 \mathrm{~m}$ of tuffs, sometimes sandy tuffites, lithic tuffs (tufolites), and chonites of greatly varied coloration, generally in tabular strata; also present are very subordinate amounts of fine-grained conglomerates.

There are also carbonaceous pelitic levels, up to true coals, which are generally located near the base of the sequence cropping out in the Gran Bajo de San Julián sector, particularly in the Laguna del Carbón and Barda Blanca localities (Figs. 1.3, 2). Woods and some other fossil conchostracans, pelecypods, insects, and anurans (Stipanicic and Reig, 1957; Gallego, 1994;
Morton and Herbst, 2001; Baez and Nicoli, 2003) are associated in these levels. The rest of the abundant wood is distributed throughout the formation. The base of the Bahía Laura Group is either the Roca Blanca Formation (Lower Jurassic) or the Bajo Pobre Formation (probably Aalenian-Bajocian) (Panza and Irigoyen, 1995). The top is constituted by a series of brown clays (San Julián Formation), which, because they contain a fossil flora of angiosperm leaves, would be assigned to the Cenozoic (De Giusto, 1955; Bertels, 1977; De Giusto et al., 1980).

The age of the Bahía Laura Group is still subject to some dispute. In modern times, by means of radiometric dating, different authors have offered different age data, but all coincide between $157 \mathrm{Ma}$ and $162 \mathrm{Ma} \pm 5-10 \mathrm{Myr}$; this means the $\mathrm{La}$ Matilde Formation can be assigned to the Bathonian interval up to the Callovian (Spalletti et al., 1982; De Barrios, 1993; Echeveste et al., 2001).

Paleoenvironmentally, the La Matilde Formation sediments indicate that it is a continental sequence, characteristic, in part, of a low-energy fluvial environment; in the flood plains, some bodies of water (lagoons) formed in some areas that partly came to be of marsh conditions (lentic and reducing). In the region, an intense volcanism developed, producing the extensively distributed ash and other pyroclastic products that constitute the bulk of the sediments (Mazzoni et al., 1981; De Barrios et al., 1999). 


\section{Materials and methods}

The specimens described come from the La Matilde Formation, Santa Cruz Province, Argentina, (Fig. 1.1) and were collected from the Bajo El Puma locality of the central and south-western sector and another four localities from the Gran Bajo de San Julián sector: Laguna La Guadalosa (Estancia El Mineral), Cerro Conito, Barda Blanca and the northern part of Estancia Meseta Chica (Estancia Meseta Chica), and the south-east border of Laguna del Carbón (Estancia La Silvita) (Figs. 1.2, 3). The in situ petrified woods and rolled trees reach diameters of up to $2.4 \mathrm{~m}$ (Fig. 2).

Fragments of silicified wood showing good cellular preservation were analyzed. Standard petrographic thin-sections were prepared for the wood fragments oriented along three planes: radial longitudinal (RLS), tangential longitudinal (TLS), and transverse (TS). In addition, techniques based on acetate peels and dissociated material (Jones and Rowe, 1999) also were employed. Thin-sections were studied in detail under a Leica microscope (DM500) and microphotographs were taken by digital camera (Leica ICC50) with Leica Application Suite EZ 3.2.3 software and a scanning electron microscope (SEM Jeol 5800LV) at the Universidad Nacional del Nordeste (Corrientes, Argentina).

The wood has been described in accordance with the list of microscopic features for softwood identification (García Esteban et al., 2002, 2003; Richter et al., 2004). Greguss's (1955) glossary of terms and the standard measurements established by Chattaway (1932) are followed. At least 20 individual measurements of the various anatomical elements were recorded, giving values for means, maxima and minima, and occasionally the maximum number established (e.g,. $42 \mu \mathrm{m}$ [25-66 $\mu \mathrm{m}]$ or 3-14 [35] cells).

Systems of nomenclature and nomenclatural reviews are those found in Bamford and Philippe (2001) and Philippe and Bamford (2008).

Repository and institutional abbreviations.-Specimens and microscopic slides are deposited in the paleontological collection of the Universidad Nacional de Nordeste (UNNE) "Dr. Rafael Herbst" Paleobotany Section (CTES-PB) and (CTES-PMP), Corrientes, Argentina.

\section{Systematic paleobotany}

\author{
Order Coniferales Engler, 1897 \\ Family Araucariaceae Henkel and Hochstetter, 1865 \\ Genus Agathoxylon Hartig, 1848
}

Type species._Agathoxylon cordaianum Hartig, 1848, p. 188.

Remarks.-According to the criteria of Bamford and Philippe (2001), Philippe and Bamford (2008), and Rößler et al. (2014), the genus Agathoxylon Hartig has nomenclatural priority over the genera Araucarioxylon and Dadoxylon; hence, the La Matilde Formation specimens are assigned to Agathoxylon Hartig.

Agathoxylon agathioides (Kräusel and Jain) new combination Figures 3, 4.1, 4.2.
1964 Dadoxylon agathioides Kräusel and Jain, p. 59, pl. 1, figs. 1-3, pl. 3, figs. 14, 15, text-figs. 1, 4.

1974 Araucarioxylon agathioides (Kräusel and Jain); Bose and Maheshwari [seen in Yadav and Bhattacharyya, 1996, p. 59].

Holotype.-24288/255 B.S.I.P. from Mandro, Rajmahal Hills, Bihar, India (Jurassic).

Description.- Several fragments of silicified wood found in situ in the Barda Blanca, Cerro Conito, and Laguna La Guadalosa localities from the Gran Bajo de San Julián sector and Bajo El Puma locality (Figs. 1,2) of the central and south-western sector were analyzed. The $\log$ s found in situ measure up to $1.50 \mathrm{~m}$ in diameter, and one of the logs reaches up to $4 \mathrm{~m}$ long by $1.10 \mathrm{~m}$ in diameter. Specimen CTES-PB 10647 has a wavy external appearance due to the effects of pressure during fossilization, because in making the conventional cuts it is observed that in the same section it shows a mixture of longitudinal radial and tangential and cross-sections. All specimens correspond to pycnoxylic wood, decorticated and with good preservation of the secondary xylem. The description is based on the specimen from the Barda Blanca locality (CTES-PB 10659), although examination of the other specimens supports it (Tables 1, 2). This specimen, in TS, does not show growth rings nor are they observed with the microscope, even though at first glance they are apparently well marked, which is due to the presence of "shearing zones" sensu Erasmus (1976) (Fig. 3.1). In TS, the tracheids have rectangular-quadrangular to polygonal outlines. The radial diameter of the tracheids is $31 \mu \mathrm{m}(15-37 \mu \mathrm{m})$ and the tangential is $33 \mu \mathrm{m}(22-45 \mu \mathrm{m})$. The average number of rows of tracheids separating the rays is 4 , with a range of $1-11$. The rays are presented in a non-continuous way through the section (Fig. 3.1). In RLS, the wood type (tracheid radial pitting) is araucarian (100\% of the contiguous pits are araucarioid). Pits are bordered, uniseriate, and flattened (35\% [32-38\%]) biseriate, hexagonal, and alternate (32\% [29-37\%]), and occasionally triseriate or bi-triseriate, hexagonal, alternate, or opposite $(0.4 \%$ [0-1\%]). In addition, they are uniseriate, with biseriate portions (32\% [30-36\%]), flattened, and hexagonal, alternate (23\% [21-25\%]) and opposite in a single pair (8\% [6-12\%]) or in several pairs (1\% [0-2\%]). Rare groups of 6-10 pits are recognized; they start and end with a single pit and have portions without pitting in the walls of the tracheids. The size of the biseriate pits is $15 \times 15 \mu \mathrm{m}$ and the uniseriate pits are $15 \times$ $11 \mu \mathrm{m}$. The aperture is cross-like (internal and external elliptical aperture), measuring $15 \times 4 \mu \mathrm{m}$ or $11 \times 4 \mu \mathrm{m}$, or circular measuring $7.5 \mu \mathrm{m}$ (Figs. 3.2, 3.3, 3.4, 3.5, 4.1, 4.2). Cross-fields show an araucarioid type arrangement, with 2-6 araucarioid pits (circular aperture) or cupressoid pits (elliptical aperture) whose frequency range is $4-6$, arranged in groups or in horizontal or vertical rows. In some marginal cross-fields, 7-8 pits can be observed (Fig. 3.6, 3.7). In TLS, the radial system is homogeneous, with homocellular, uniseriate rays $(84 \%)$, and some partially biseriate rays with $1-3$ cells $(16 \%)$. The height ranges from 1-22, 37 cells, with an average of seven cells. The radial end cells are elliptical and the central ones are rectangularovoid, and they measure $26 \times 22 \mu \mathrm{m}, 30 \times 26 \mu \mathrm{m}$, or $34 \times 30 \mu \mathrm{m}$ in width and height. In tangential and radial section, the 


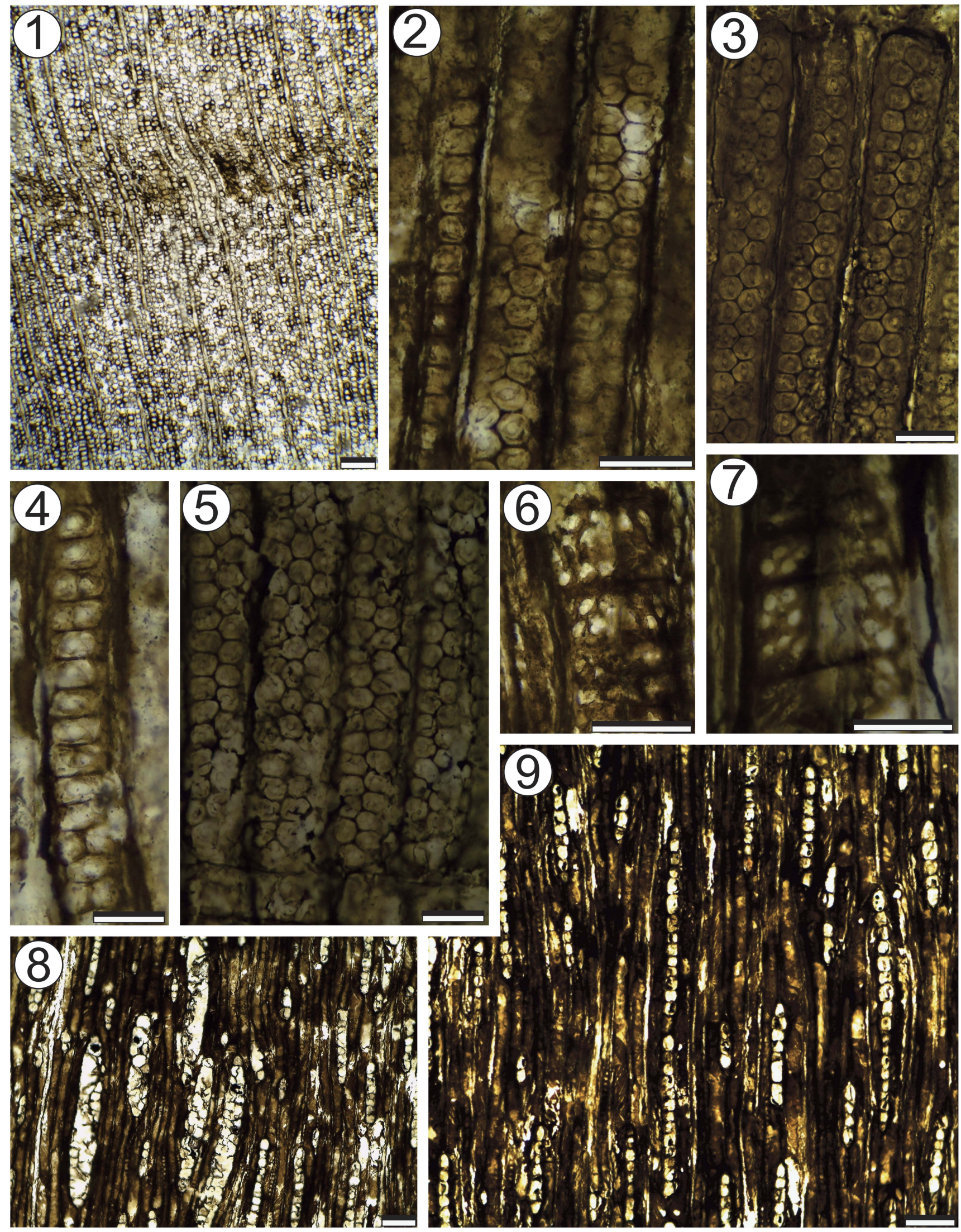

Figure 3. Agathoxylon agathioides. (1) TS, detail of the tracheids; (2-5) RLS, pits on tracheid radial walls; (6, 7) RLS, detail of cross-field pits; (8, 9) TLS, rays; $(\mathbf{8})$ biseriate rays produced as a reaction to vascular cambium damage. Scale bars: $(\mathbf{1})=150 \mu \mathrm{m} ;(\mathbf{2}-\mathbf{7})=30 \mu \mathrm{m} ;(\mathbf{8 , 9})=110 \mu \mathrm{m}$. $(\mathbf{1}, \mathbf{2}, \mathbf{4 ,} \mathbf{6}-\mathbf{9})$ CTES PB 10659. $(\mathbf{3}, \mathbf{5})$ CTES PB 14236. 

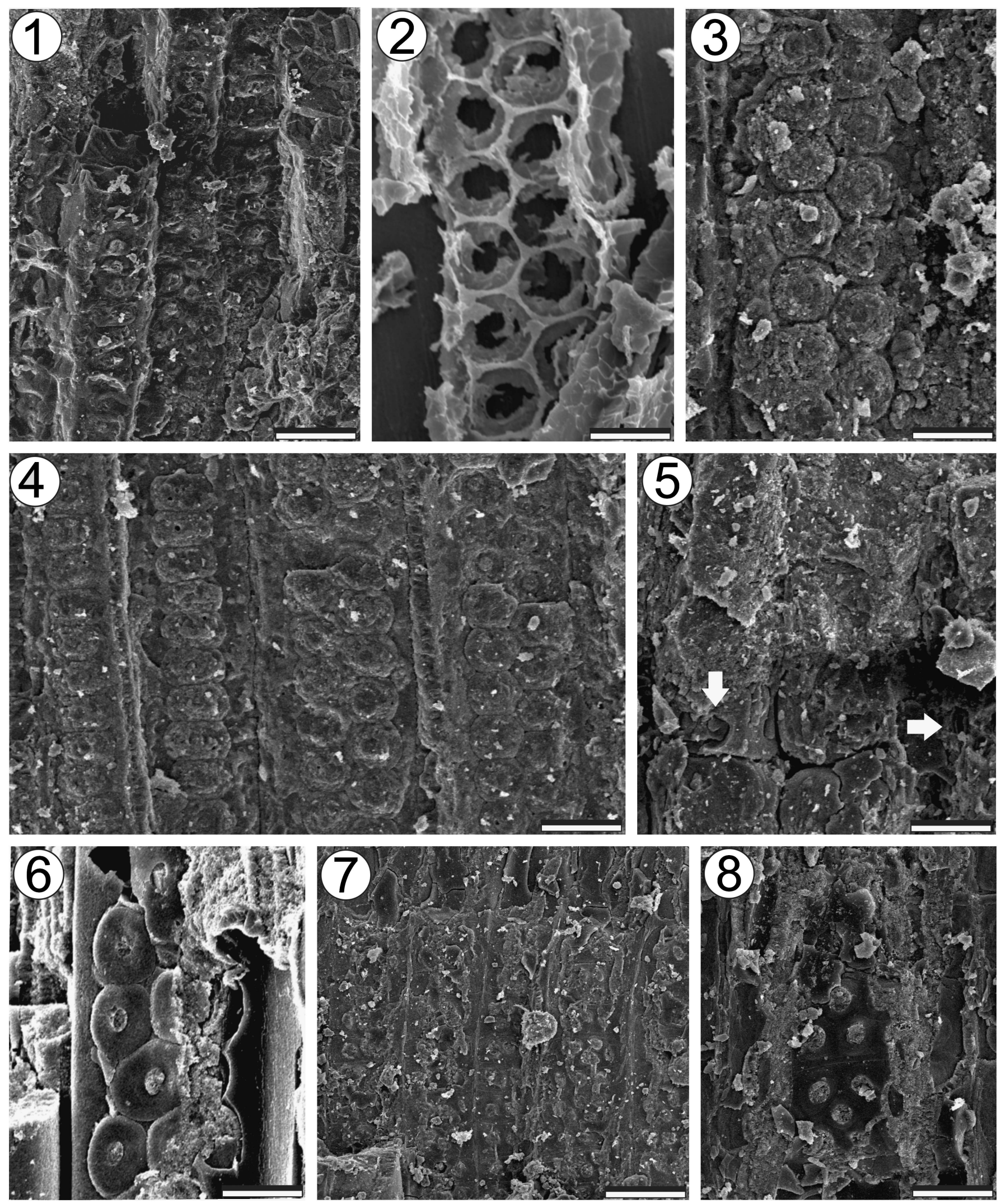

Figure 4. (1, 2) Agathoxylon agathioides. (3-5) Agathoxylon santalense. (6-8) Agathoxylon termieri. (1-4, 6) RLS, pits on tracheid radial walls; (5-8) RLS, detail of cross-field pits (white arrows). Scale bars: $(\mathbf{1}, \mathbf{2})=30 \mu \mathrm{m} ;(\mathbf{3}-\mathbf{5})=40 \mu \mathrm{m} ;(\mathbf{6}-\mathbf{8})=35 \mu \mathrm{m}$. (1, 2) CTES PB 10659. (3-5) CTES PB 10649. (6-8) CTES PB 10693 
Table 1. Quantitative data expressed in percentages; the following characters are combined: seriations radial pitting tracheids (column 1), type and shape of radial pitting tracheids (column 2: lineal schemes). M-M (m)= Minimum-Maximum (mean). Agathoxylon agathioides A1 = CTES-PB 10659; $\mathrm{A} 2=\mathrm{CTES}-\mathrm{PB}$ 10647; A3 = CTES-PB 14236; A4 = CTES-PB 10703; A5 = CTES-PB 10702; A6 = CTES-PB 12036; Agathoxylon santalense B1 = CTES-PB 10649; B2= CTES-PB 14239; B3 = CTES-PB 10665; Agathoxylon termieri C1 = CTES-PB 10693; C2 = CTES-PB 10696; C3 = CTES-PB 10675; C4 = CTES-PB 12043; C5 = CTES-PB 12041; Agathoxylon santacruzense D = CTES-PB 12012.

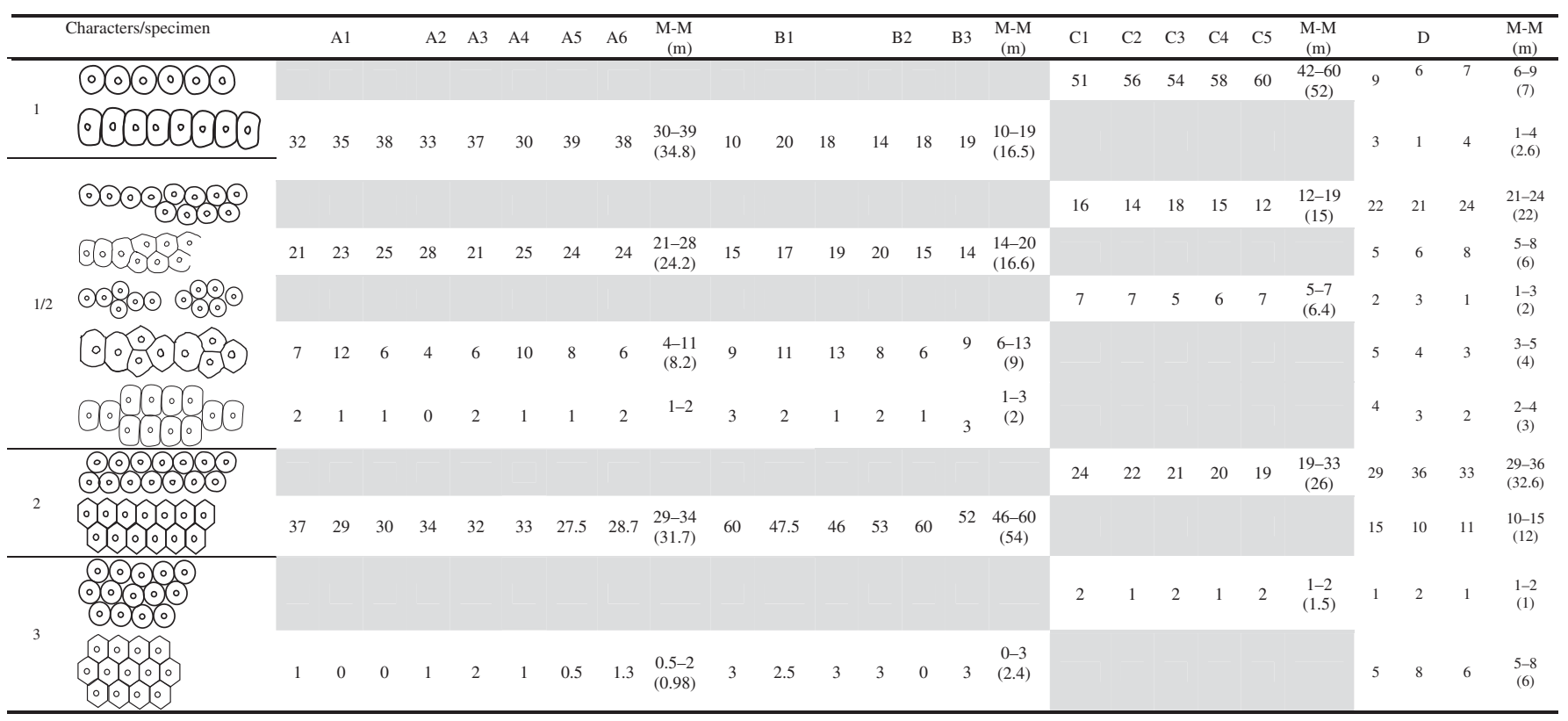

tracheids are recognized with resins, generally distributed near the rays. The resins occupy the entire wall of the tracheids in the form of resin plates. In some areas, fully biseriate rays can be observed, probably produced as a reaction to vascular cambium damage (Fig. 3.8, 3.9). The rameal and/or foliar traces are elliptical and measure $750 \mu \mathrm{m}$ long, with some preserved tracheids $7.5-15 \mu \mathrm{m}$ in diameter.

Materials._Gran Bajo de San Julián sector: Barda Blanca: CTES-PB 10647 (CTES-PMP 2324-2325); CTES-PB10659 (CTES-PMP 2353 a, b, c); CTES-PB 14236 (CTES-PMP 3535 a, b, c); CTES-PB 14237 (CTES PMP- 3536 a, b, c); CTES-PB 14238 (CTES-PMP 3537 a, b, c). Cerro Conito: CTES-PB 10702 (CTES-PMP 2426 a, b, c); CTES-PB 10703 (CTES-PMP 2386 a, b, c). NW Laguna La Guadalosa: CTES-PB 12033 (CTES-PMP 2372 a, b, c); CTES-PB 12034 (CTES-PMP 2365 a, b, c); CTES-PB 12035 (CTES-PMP 2366 a, b, c); CTES-PB 12036 (CTES-PMP 2369 a, b, c). Central and south-western sector: Bajo El Puma: CTES-PB 14208 (CTES-PMP 3532 a, b, c); CTES-PB 14209 (CTES-PMP 3533 a, b, c); CTES-PB 14210 (CTES-PMP 3534 a, b, c).

Remarks.-The description above coincides with the characters given by Kräusel and Jain (1964) for the taxon Dadoxylon agathioides. These materials are characterized by araucarian secondary wood types with mostly uniseriate to biseriate, some triseriate, alternate, flattened, and hexagonal radial pitting. Furthermore, they are arranged in groups over short distances of one to several pits, with rays of 2-20 cells in height and crossfields with 2-8 pits arranged in an araucarioid pattern (Kräusel and Jain, 1964). The specific epithet of this species comes from Kräusel and Jain's (1964) comparison of this wood with some species of the genus Agathis Salisb, noting that they shared the cross-like shape of the opening of the pits and similar grouping of the pits in the radial walls of the tracheids, but this latter character is also observed in some species of Araucaria Juss (Kräusel and Jain, 1964).

Tables 1 and 2 summarize the observed characters of six specimens from the La Matilde Formation, and quantitative data from three different portions of the early wood in sample CTESPB 10659 are given. In the same data, it is possible to appreciate a certain uniformity in the percentages of the different combinations of the pits of the radial walls of the tracheids, but with a predominance of uni-biseriate pits. In addition, variability is observed in the number of pits in the cross-fields, but, always within the range of 2-8, some arranged in groups of 5-6, as in a specimen from India (Kräusel and Jain, 1964). Also, it reflects differences in the height of the rays, with the Patagonia specimens occasionally exhibiting up to 40 cells.

These differences do not invalidate the assignment of the specimens described here to Agathoxylon agathioides because they agree with most of the diagnostic characters. Agathoxylon agathioides (Kräusel and Jain) n. comb. is comparable to several species of Araucarioxylon, Agathoxylon, and Dadoxylon from Gondwana owing to the presence of hexagonal araucarioid pits, but it is identifiable by the presence of clusters of groups of pits and by the set of diagnostic characters (Table 3).

Agathoxylon santalense (Sah and Jain) new combination Figures 4.3, 4.4, 4.5, 5

1964 Dadoxylon santalense Sah and Jain, p. 178, pl. 2, fig. 11, pl. 3, figs. 15-18, text.figs. 9, 10.

1974 Araucarioxylon santalense (Sah and Jain); Bose and Maheshwari [seen in Yadav and Bhattacharyya, 1996, p. 59]. 


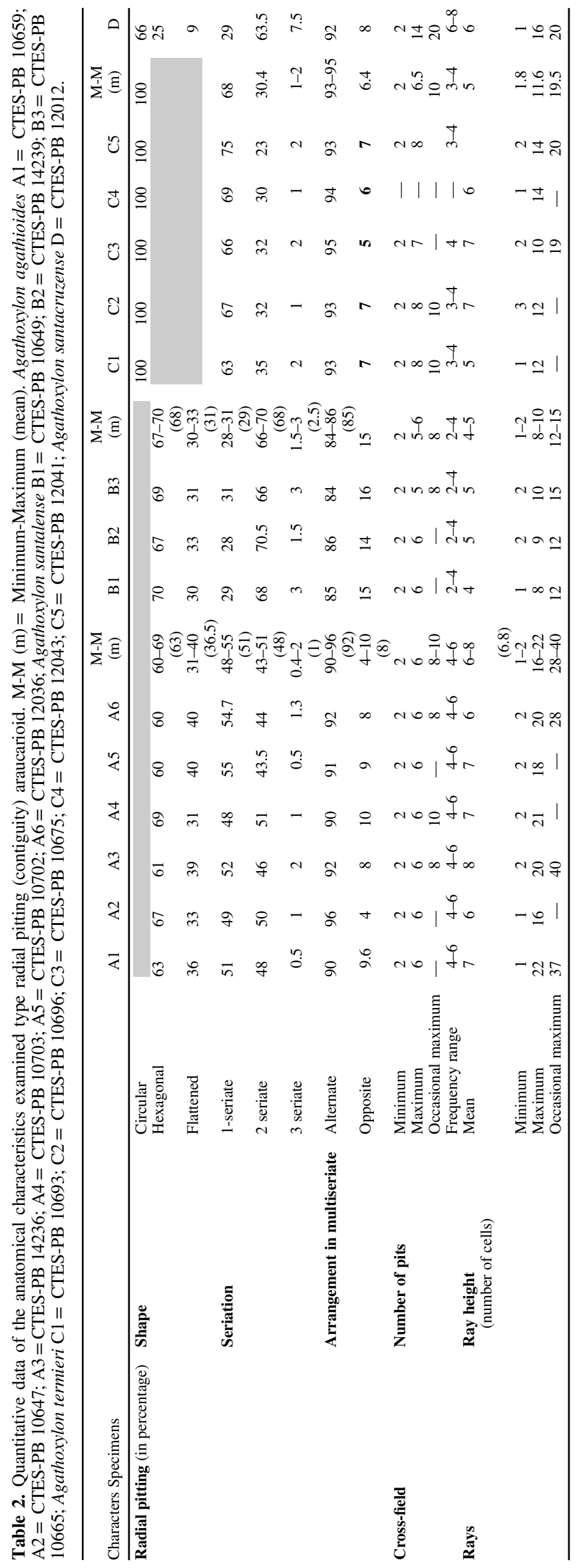

Holotype.—4506 B.S.I.P. from Mandro, Rajmahal Hills, Bihar, India (Jurassic).

Description.-Wood fragments found in situ of $95 \mathrm{~cm}$ in diameter, and a trunk of $1.20 \mathrm{~m}$ long and $30 \mathrm{~cm}$ in diameter were studied. These materials come from the Barda Blanca locality of the Gran Bajo de San Julián sector and Bajo El Puma locality of the central and south-western sector (Figs. 1, 2). The description is based on specimen CTES-PB 10649, although examination of the other specimens supports it. Secondary xylem is pycnoxylic with distinct growth ring boundaries, and the transition from early wood to late wood is gradual. In TS, the tracheids are quadrangular-rectangular and irregular in shape. The radial diameter of the tracheids is $59 \mu \mathrm{m}(45-82 \mu \mathrm{m})$ and the tangential is $50 \mu \mathrm{m}(30-75 \mu \mathrm{m})$. The average number of tracheids separating the rays is 10 , with a range of 3-26 tracheids. The rays are displayed in a continuous way through the section (Fig. 5.1). In RLS, the wood secondary type (tracheid radial pitting) is araucarian (100\% of the contiguous pits are araucarioid). In the early wood, pits are bordered, uniseriate, flattened (16\% [10-20\%]), biseriate, hexagonal, and alternate (53\% [46-60\%]), and occasionally triseriate or bi-triseriate, hexagonal, and alternate (3\% [2.5-3\%]); in addition, they are uniseriate, with biseriate portions (30\% [27-33\%]), flattened and hexagonal, alternate (17\% [15-19\%]) and opposite in a single pair (11\% [9-13\%]) or in a several pairs (2\% [1-3\%]). In the late wood, pits are bordered, uniseriate and flattened. The size of the pits is $15-30 \mu \mathrm{m} x$ $15 \mu \mathrm{m}$. The pits present a central circular aperture, which measures 6-7.5 $\mu \mathrm{m}$ (Figs. 4.3, 4.4, 5.2, 5.3). Cross-fields show an araucarioid type arrangement, with 2-6 araucarioid pits, measuring $11 \mu \mathrm{m}$ with a circular aperture of $4 \mu \mathrm{m}$, whose frequency range is $3-4$, arranged in groups or in horizontal rows. In some marginal cross-fields, 9-12 pits can be observed (Figs. 4.5, 5.4). In TLS, the radial system is homogeneous with homocellular rays, uniseriate, of $1-8,12$ cells in height, with an average of $4-5$ cells. The central cells are ovoidal and measure $15-30 \mu \mathrm{m} \mathrm{x}$ $22-30 \mu \mathrm{m}$ in width by height, respectively. Tracheids are observed with resins associated with the rays, which in radial and tangential section form the typical biconcave plates or "resin plates" (Fig. 5.5).

Materials.-Gran Bajo de San Julián sector: Barda Blanca: CTES-PB 10649 (CTES-PMP 2328-2329); CTES-PB10665 (CTES-PMP $2321 \mathrm{a}, \mathrm{b}, \mathrm{c}$ ), CTES-PB 14239 (CTES-PMP 3538 a, b, c); CTES-PB 14240 (CTES-PMP 3539 a, b, c); Center and south western sector, Bajo El Puma: CTES-PB 14206 (CTESPMP 3530 a, b, c); CTES-PB 14207 (CTES-PMP 3531 a, b, c).

Remarks.-After comparison with species of the genera Araucarioxylon and Dadoxylon, the specimen from the La Matilde Formation was determined to be Agathoxylon santalense (Sah and Jain) n. comb. This species was erected by Sah and Jain (1964) as Dadoxylon santalense and is characterized by araucarian wood types with mostly uniseriate, sometimes biseriate, alternate, flattened, and hexagonal radial pitting; cross-fields with 2-6 pits arranged in an araucarioid pattern, usually four, with the aperture as big as the border and rays of 110 cells in height; and resin tracheids present, associated with the rays (Table 3 ). 
Table 3. $(1,2)$ Comparison between some species of Agathoxylon/Araucarioxylon/Dadoxylon from Gondwana sharing the characters: presence of flattened and hexagonal and alternate (opposite) pits in the radial walls of the tracheids. (1/2: rays uniseriate partially biseriate; in parentheses $=$ character with occasional condition).

\begin{tabular}{|c|c|c|c|c|c|c|}
\hline CHARACTERS/SPECIES & $\begin{array}{l}\text { RADIAL } \\
\text { WALLS PITS }\end{array}$ & $\begin{array}{l}\text { CROSS- } \\
\text { FIELD }\end{array}$ & $\begin{array}{l}\text { RAYS } \\
\text { WIDTH }\end{array}$ & $\begin{array}{l}\text { RAYS } \\
\text { HEIGHT }\end{array}$ & ORIGIN/REFERENCE & AGE \\
\hline $\begin{array}{l}\text { A. manieroi (Krausel and Dolianiti) } \\
\text { Maheshwari }\end{array}$ & $1-4$ & $1-9$ & - & $1-47$ & $\begin{array}{l}\text { Brazil } \\
\text { Kräusel and Dolianiti, 1958; Maheshwari, } 1972\end{array}$ & Upper Carboniferous \\
\hline A. gondwanense (Maithy) Maheshwari & $3-4(1-5)$ & $2-8$ & $1(1 / 2)$ & $1-43$ & $\begin{array}{l}\text { India } \\
\text { Maithy, 1964; Maheshwari, } 1972\end{array}$ & Lower Permian \\
\hline $\begin{array}{l}\text { A. ningahense (Maheshwari) Crisafulli } \\
\text { and Herbst }\end{array}$ & $1-4$ & $1-6$ & $1(2)$ & $1-11$ & $\begin{array}{l}\text { India, Antarctica, Uruguay, Argentina } \\
\text { Maheshwari, 1964; Crisafulli and Lutz, 1997; } \\
\text { Crisafulli and Herbst, } 2008\end{array}$ & $\begin{array}{l}\text { Upper Permian } \\
\text { Lower Permian }\end{array}$ \\
\hline A. surangei Agashe, Prasad, and Suresh & $1-4$ & $1-11$ & $1-2$ & $1-35$ & $\begin{array}{l}\text { India } \\
\text { Agashe et al., } 1981\end{array}$ & Permian \\
\hline A. nummularium (Maniero) Maheshwari & $1(2)$ & Numerous & $1(2)$ & $1-30$ & $\begin{array}{l}\text { Brazil, Uruguay } \\
\text { White, 1908; Maniero, 1946; Kräusel and Dolianiti, } \\
\text { 1958; Maheshwari, 1972; Crisafulli, } 2001\end{array}$ & Permian \\
\hline A. parbeliense (Rao) Maheshwari & $1-5$ & $8-9$ & 1 & $1-24$ & $\begin{array}{l}\text { India } \\
\text { Rao, 1935; Maheshwari, } 1972\end{array}$ & Permian \\
\hline A. nadorii Vagyani and Raju & 1-multiseriate & $2-6$ & $1(2)$ & $2-30$ & $\begin{array}{l}\text { India } \\
\text { Vagyani and Raju, } 1981\end{array}$ & Upper Permian \\
\hline A. roxoi (Maniero) Krausel and Dolianiti & $1-2$ & $2-4(5-6)$ & 1 & $1-36$ & $\begin{array}{l}\text { Brazil, Uruguay } \\
\text { Maniero 1946; Kräusel and Dolianiti, 1958; } \\
\text { Maheshwari, 1972; Crisafulli, } 2001\end{array}$ & Upper Permian \\
\hline $\begin{array}{l}\text { D. sudanense Duperon-Laudoueneix and } \\
\text { Lejal-Nicol }\end{array}$ & $2-3(1-4)$ & $1-6$ & $1(1 / 2)$ & $1-26$ & $\begin{array}{l}\text { Africa } \\
\text { Duperon-Laudoueneix and Lejal-Nicol, } 1981\end{array}$ & Permian-Triassic \\
\hline A. africanum Bamford & $2(1)$ & $2-7$ & 1 & $2-18$ & $\begin{array}{l}\text { South Africa } \\
\text { Bamford, } 2000\end{array}$ & $\begin{array}{l}\text { Upper Permian- } \\
\text { Lower Triassic? }\end{array}$ \\
\hline A. karooensis Bamford & $2(1-3)$ & $2-4$ & $1(2)$ & $3-25$ & $\begin{array}{l}\text { South Africa } \\
\text { Bamford, } 2000\end{array}$ & $\begin{array}{l}\text { Upper Permian- } \\
\text { Lower Triassic? }\end{array}$ \\
\hline $\begin{array}{l}\text { D. sudanense Duperon-Laudoueneix } \\
\text { and Lejal-Nicol }\end{array}$ & $1-5$ & $1-4$ & $1(2)$ & $1-26$ & $\begin{array}{l}\text { Africa } \\
\text { Duperon-Laudoueneix and Lejal-Nicol, } 1981\end{array}$ & Permian-Triassic \\
\hline D. parenchymatosum Vogellehner & $2(1)$ & $3-4$ & $1(2)$ & $2-12$ & $\begin{array}{l}\text { South Africa } \\
\text { Vogellehner, } 1965\end{array}$ & Permian-Triassic \\
\hline $\begin{array}{l}\text { D. tordoxyloides Vozenin-Serra and } \\
\text { Salard-Cheboldaeff }\end{array}$ & $1(2)$ & $2-4$ & 1 & $2-34$ & $\begin{array}{l}\text { New Caledonia, Australia } \\
\text { Vozenin-Serra and Salard-Cheboldaeff, } 1992\end{array}$ & Permian-Triassic \\
\hline D. agathiodes Krausel and Jain & 1-2 (3) groups & $2-8$ & $1(1 / 2)$ & $2-20$ & $\begin{array}{l}\text { India } \\
\text { Kräusel and Jain, } 1964\end{array}$ & Lower Cretaceous \\
\hline $\begin{array}{l}\text { A. agathioides (Kräusel and Jain) nov. comb. } \\
\text { D. bindrabanense Sah and Jain }\end{array}$ & $\begin{array}{l}1-2(3) \text { groups } \\
2-3(1)\end{array}$ & $\begin{array}{l}2-6,10 \\
4-12\end{array}$ & $\begin{array}{l}1(1 / 2) \\
1\end{array}$ & $\begin{array}{l}1-22(28-40) \\
1-45\end{array}$ & $\begin{array}{l}\text { Argentina this work } \\
\text { India } \\
\text { Sah and Jain, } 1964\end{array}$ & $\begin{array}{l}\text { Middle Jurassic } \\
\text { Lower Cretaceous }\end{array}$ \\
\hline D. (A.) jurassicum Bardwaj & $1-2$ & $4-8$ & 1 & $1-11$ & $\begin{array}{l}\text { India } \\
\text { Bhardwaj, } 1953\end{array}$ & Lower Cretaceous \\
\hline $\begin{array}{l}\text { A. santalense } \\
\text { Sah and Jain }\end{array}$ & $1-2(3)$ & $2-7$ & $1(2)$ & $1-12$ & $\begin{array}{l}\text { India } \\
\text { Sah and Jain, } 1964\end{array}$ & Lower Cretaceous \\
\hline A. santalense (Sah and Jain) n. comb. & $1-2(3)$ & $2-6,8$ & 1 & $1-8(12-15)$ & $\begin{array}{l}\text { Santa Cruz, Argentina } \\
\text { this work }\end{array}$ & Middle Jurassic \\
\hline D. mandroense Sah and Jain & $\begin{array}{l}\text { EW: } 1-3 \\
\text { LW: } 1-2\end{array}$ & $\begin{array}{l}\text { WE: } 4-12 \\
\text { LW: 2-6 }\end{array}$ & 1 & $1-15$ & $\begin{array}{l}\text { India } \\
\text { Sah and Jain, } 1964\end{array}$ & Lower Cretaceous \\
\hline A. mosurense Jeyasingh and Kumarasamy & $1-2(3-4)$ & $2-6$ & $1(1 / 2-3)$ & $1-27$ & $\begin{array}{l}\text { India } \\
\text { Jeyasingh and Kumarasamy, } 1995\end{array}$ & Cretaceous \\
\hline Araucarioxylon sp. 1 Falcon-Lang and Cantrill & $1-2(3)$ & $2-9$ & $1(2)$ & $1-23$ & $\begin{array}{l}\text { Antarctica } \\
\text { Falcon-Lang and Cantrill, } 2001\end{array}$ & Lower Cretaceous \\
\hline $\begin{array}{l}\text { Araucarioxylon sp. } 2 \\
\text { Falcon-Lang and Cantrill }\end{array}$ & $1-3$ & $2-8$ & $1(2)$ & $1-11$ & $\begin{array}{l}\text { Antarctica } \\
\text { Falcon-Lang and Cantrill, } 2001\end{array}$ & Lower Cretaceous \\
\hline A. resinosum (Shulka) Trivedi and Srivastava & $1-4$ & $1-10$ & $1-2$ & $1-39$ & $\begin{array}{l}\text { India } \\
\text { Shukla 1944; Trivedi and Srivastava, } 1989\end{array}$ & Cenozoic \\
\hline $\begin{array}{l}\text { A. shuklai (Singhai) } \\
\text { Trivedi and Srivastava }\end{array}$ & $1-2,3$ & $1-2$ & 1 & $2-30$ & $\begin{array}{l}\text { India } \\
\text { Singhai 1958; Trivedi and Srivastava, } 1989\end{array}$ & Cenozoic \\
\hline $\begin{array}{l}\text { A. chhindwarensis (Billimoria) Trivedi and } \\
\text { Srivastava }\end{array}$ & $1-3$ & $1-7$ & $1-2$ & - & $\begin{array}{l}\text { India } \\
\text { Billimoria, 1948; Trivedi and Srivastava, } 1989\end{array}$ & Cenozoic \\
\hline A. mohgaoensis Lakhanpal, Prakash, and Bande & $2(1-3)$ & $1-2$ & 1 & $2-15(-30)$ & $\begin{array}{l}\text { India } \\
\text { Lakhanpal et al., } 1977\end{array}$ & Cenozoic \\
\hline A. pichasquense Torres and Rallo & $1-2$ & $3-14$ & $1(1 / 2)$ & $1-14(-25)$ & $\begin{array}{l}\text { Chile } \\
\text { Torres and Rallo, 1981; Nishida et al., } 1992\end{array}$ & $\begin{array}{l}\text { Upper Cretaceous- } \\
\text { Cenozoic }\end{array}$ \\
\hline A. kellerense Lucas and Lacey & $1-3$ & $1-5$ & $1(1 / 2)$ & $1-15(-25)$ & $\begin{array}{l}\text { Chile. Lucas and Lacey, } 1981 \\
\text { Antarctica. Nishida et al., } 1992\end{array}$ & $\begin{array}{l}\text { Upper Cretaceous- } \\
\text { Cenozoic }\end{array}$ \\
\hline $\begin{array}{l}\text { A. antarcticus (Poole and Cantrill) Pujana, } \\
\text { Santillana, and Marenssi }\end{array}$ & $1-2$ & $1-9$ & 1 & $1-16$ & $\begin{array}{l}\text { Antarctica } \\
\text { Pujana et al., } 2015\end{array}$ & Paleocene \\
\hline $\begin{array}{l}\text { A. pseudoparenchymatosum (Gothan) Pujana, } \\
\text { Santillana, and Marenssi }\end{array}$ & $1-2$ & $1-7$ & 1 & $1-7$ & $\begin{array}{l}\text { Antarctica } \\
\text { Pujana et al., } 2015\end{array}$ & Paleocene \\
\hline
\end{tabular}

This assignment is supported, essentially, by the type and number of pits in the cross-fields, by the height of the rays, and resin in the tracheids. The Argentine material differs in having rarely triseriate radial pitting; resins in the radial cells as well as in the tracheids associated with the rays; and because it shows a higher percentage of biseriate radial pitting in the early wood. In comparison, a specimen from India has mostly uniseriate pits, which would probably correspond mostly to late wood.
This species is similar to Araucarioxylon/Dadoxylon and Agathoxylon in the presence of uniseriate, flattened, and bitriseriate, hexagonal, mainly alternate, radial pitting; the differences are given in the set of diagnostic characters and the same are expressed in Table 3. Araucarioxylon santalense is very similar to Araucarioxylon sp. described by Falcon-Lang and Cantrill (2001) in most of the anatomical characters (Table 3), and to Araucarioxylon hoodii, described by Tidwell and Medlyn (1993) from the Upper Jurassic Morrison Formation (Utah, USA). The 

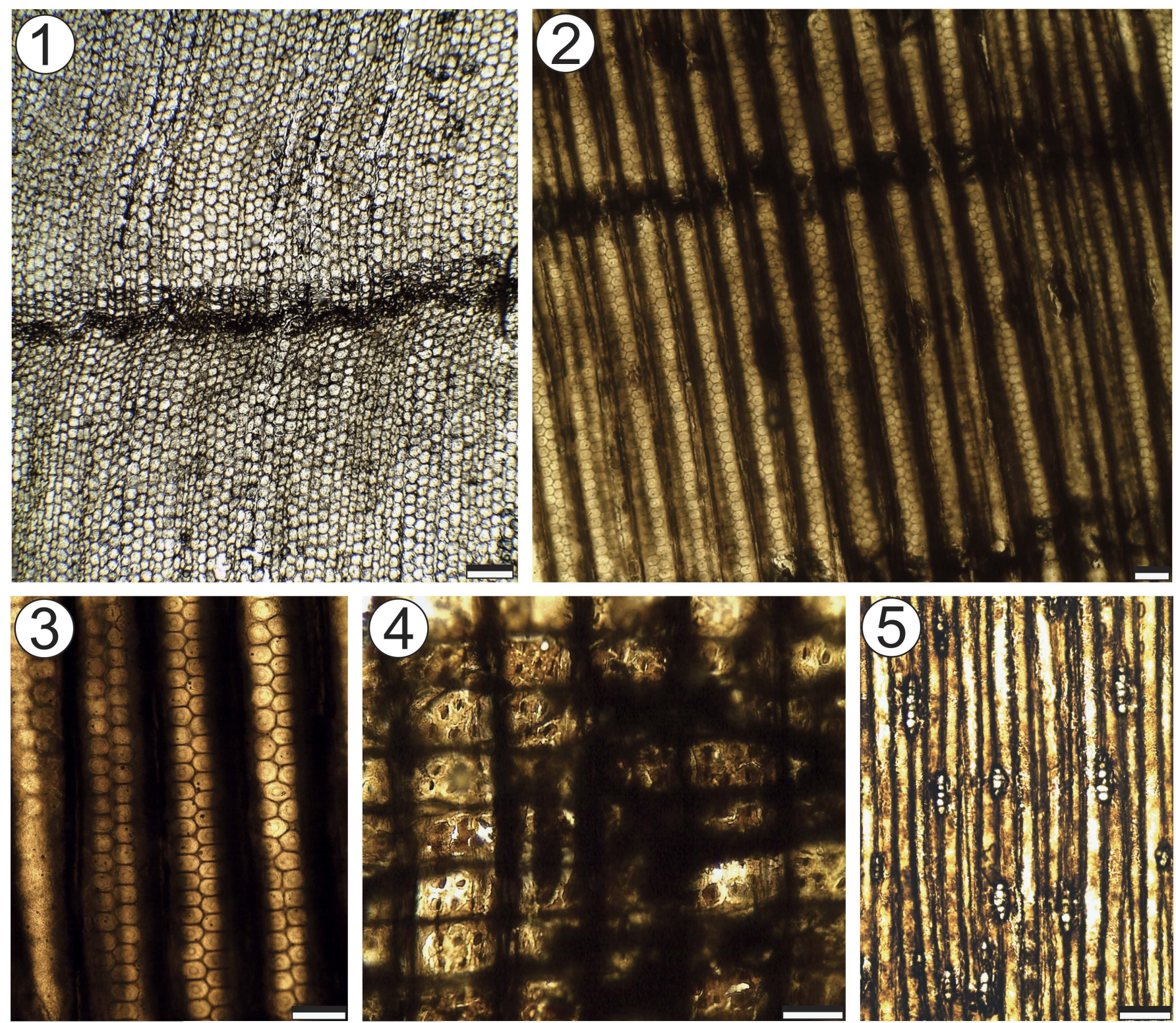

Figure 5. Agathoxylon santalense. (1) TS, detail of the tracheids and growth ring; $(\mathbf{2}, \mathbf{3})$ RLS, pits on tracheid radial walls; (4) RLS, detail of cross-field pits (5) TLS, rays and resin plates. Scale bars: $(\mathbf{1})=140 \mu \mathrm{m} ;(\mathbf{2}-\mathbf{4})=40 \mu \mathrm{m} ;(\mathbf{5})=130 \mu \mathrm{m}$. (1-4) CTES PB 10649. (5) CTES PB 14239.

latter is distinguished by the presence of pits in the tangential walls of the tracheids, the shape and number of pits in the cross-field, and the greater height of the rays.

Agathoxylon termieri (Attims) Gnaedinger and Herbst, 2009

Figures 4.6, 4.7, 4.8, 6

1965 Dadoxylon (A.) termieri Attims, p. 33.

1985 Dadoxylon (A.) termieri Attims in Giraud and Hankel p. 170 , pl. 2, fig. a-e, text-fig. 3 .

2000 Araucarioxylon allani (Kräusel) Maheshwari in Gnaedinger, p. 38.

2006 Araucarioxylon termieri Gnaedinger, p. 171, figs. 1, 2.

Holotype.-QDS 226/3 from Lias (Lower Jurassic), Morocco.

Cotype.-78-1 from Tanzania (Lower Jurassic).
Description.-Fragments of fallen wood, one of them $3 \mathrm{~m}$ long and $30 \mathrm{~cm}$ in diameter and another $1.3 \mathrm{~m}$ in diameter, were analyzed from the Cerro Conito and northern part of the Estancia Meseta Chica localities from the Gran Bajo de San Julián sector. The following description is based on specimen CTES-PB 10693 and consists of a fragment of secondary xylem, pycnoxylic, with growth ring boundaries distinct and with a gradual transition from the early wood to the late wood. In TS, the tracheids of the early wood are polygonal with a thickness of the double wall of $7.5 \mu \mathrm{m}$. The radial diameter of the tracheids is $54 \mu \mathrm{m}(37-75 \mu \mathrm{m})$ and the tangential $42 \mu \mathrm{m}(22-67 \mu \mathrm{m})$. The tracheids of the late wood are generally of rectangular outline, some polygonal. The radial diameter of the tracheids is $31 \mu \mathrm{m}$ $(22-37 \mu \mathrm{m})$ and the tangential is $43 \mu \mathrm{m}(30-60 \mu \mathrm{m})$. The average number of tracheids that separate the rays is 6 , varying between 1 and 17 tracheids (Fig. 6.1). In RLS, the wood type (tracheid radial pitting) is araucarian (100\% of the contiguous pits are 

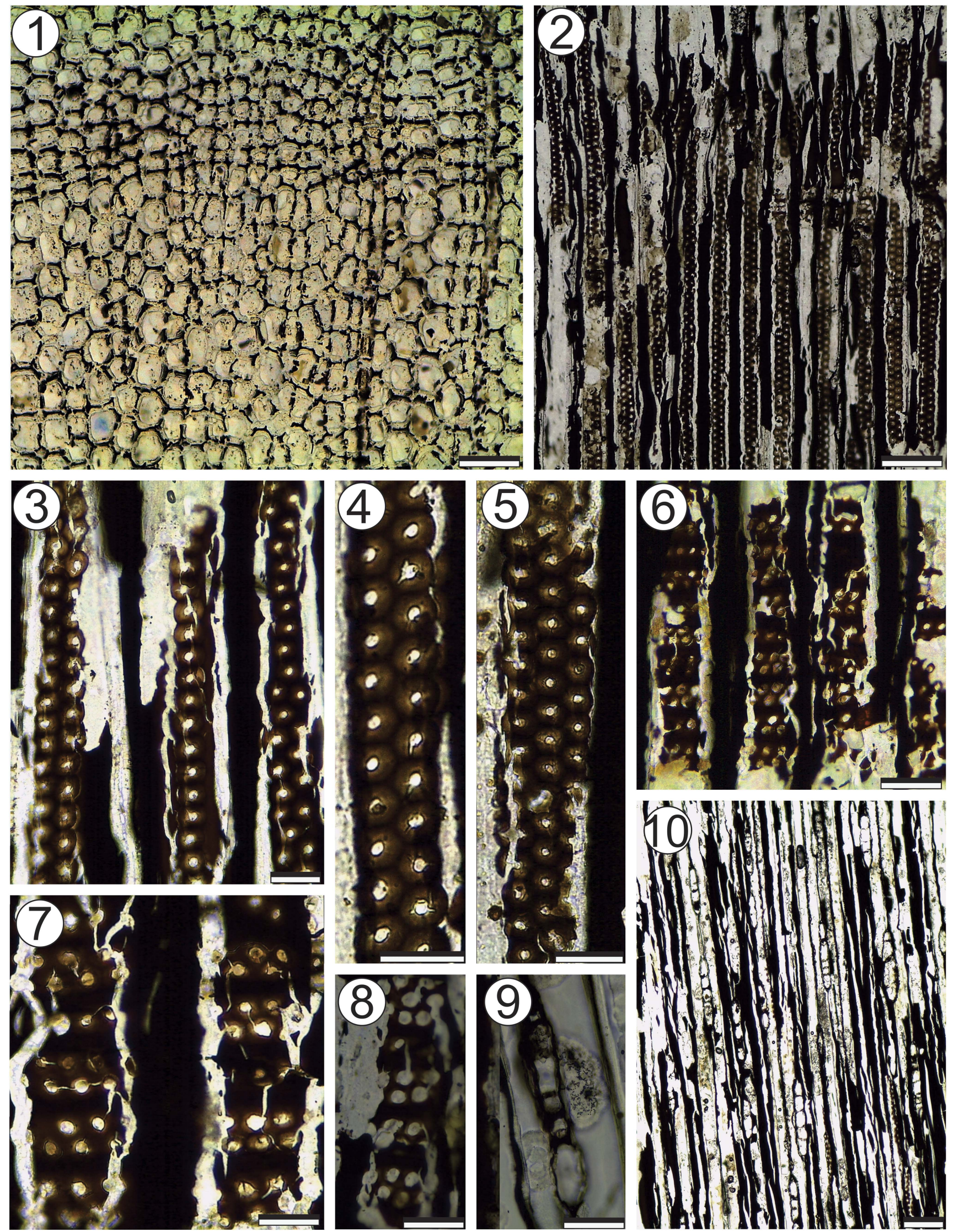

Figure 6. Agathoxylon termieri. (1) TS, detail of the tracheids and growth ring; (2-5) RLS, pits on tracheid radial walls; (6-8) RLS, detail of cross-field pits; $(\mathbf{9}, \mathbf{1 0})$ TLS, rays. Scale bars: $(\mathbf{1})=140 \mu \mathrm{m} ; \mathbf{( 2 )}=100 \mu \mathrm{m} ;(\mathbf{3 - 7})=20 \mu \mathrm{m} ; \mathbf{( 8 , 9 )}=10 \mu \mathrm{m} ;(\mathbf{1 0})=50 \mu \mathrm{m}$. CTES PB 10693. 
araucarioid). Pits are circular (100\%), araucarioid, uniseriate $(51 \%)$, alternate biseriate $(24 \%)$, uniseriate partially biseriate, alternate $(16 \%)$ and opposite $(7 \%)$, and triseriate and bi-triseriate, alternate $(2 \%)$. The size of the pits is $11-15 \mu \mathrm{m} \times 11-15 \mu \mathrm{m}$. The pits exhibit a circular aperture, which measures $7.5 \mu \mathrm{m}$ (Figs. 4.6, $6.2,6.4,6.5)$. Cross-fields are araucarioid, having $2-8,10$ pits that are circular, with circular or sometimes elliptical apertures, whose frequency range is 3-4 pits, arranged in groups or crown-shaped or in two or three horizontal rows (Figs. 4.7, 4.8, 6.6-6.8). The pits measure $12-15 \mu \mathrm{m}$ in diameter and the apertures from $4 \mu \mathrm{m}$ to $11 \mu \mathrm{m}$; some of the radial cells end in a pointed shape. In TLS, the radial system is homogeneous with homocellular rays, uniseriate, of $1-12$ cells in height; the average is $4-5$ cells. The cells at both ends are elliptical and the centers are rectangular or quadrangular, measuring $15-52 \mu \mathrm{m}$ high by $15-30 \mu \mathrm{m}$ wide. In addition, the rays show differences in the height of the central radial cells of the same rays; some radial cells measure $17-20 \mu \mathrm{m}$ and others 6-11 $\mu \mathrm{m}$ (Figs. 6.9, 10).

Materials.-Gran Bajo de San Julián sector: Cerro Conito: CTES-PB 10675 (CTES-PMP 2408-2409); CTES-PB 10693 (CTES-PMP 2381); CTES-PB 10696 (CTES-PMP 2391); CTES-PB 10697 (CTES-PMP 2392); CTES-PB 12004 (CTESPMP 2390); CTES-PB 12017 (CTES-PMP 2438); CTES-PB 14265 (CTES-PMP 3540 a, b, c); CTES-PB 14266 (CTES-PMP $3541 \mathrm{a}, \mathrm{b}, \mathrm{c})$; Northern part of Ea. Meseta Chica: CTES-PB 12041 (CTES-PMP 2459); CTES-PB 12043 (CTES-PMP 24652466); CTES-PB 12052 (CTES-PMP 2472).

Remarks.-Specimens identified as Araucarioxylon termieri (Attims) Gnaedinger and Herbst match with the description made by Giraud and Hankel (1985) for Dadoxylon (Araucarioxylon) termieri Attims and with the anatomical characters of the holotype given by Attims (1965) (see Giraud and Hankel, 1985). In addition, these specimens from Argentina show differences in the height of the central radial cells within the same ray, as in the specimen from Tanzania (Giraud and Hankel, 1985, pl. 13, fig. 3). Tables 1 and 2 summarize the observed anatomical features of five samples from the La Matilde Formation and show the numerical differences in the percentages of the seriation and combination of the radial pitting, but, always with a greater percentage of uniseriate pits, like the specimens from Africa.

Araucarioxylon termieri (Attims) Gnaedinger and Herbst is similar to other species of Agathoxylon (Araucarioxylon) from Gondwana in sharing the presence of circular pits in the radial walls of the tracheids, and is distinguished by the seriation and distribution of pits in the radial tracheid walls, the number of pits in the cross-fields, and the ray height (Table 4). However, A. termieri is identical to the Permian species Araucarioxylon allani (Kräusel) Maheshwari in presenting in the radial walls of the tracheids araucarioid, circular, uniseriate, biseriate, and rarely triseriate pits, and uniseriate, low rays, with a height of 1-12 cells (Kräusel, 1962) (Table 4); and, therefore they are probably synonymous.

\section{Agathoxylon santacruzense new species} Figures 7, 8

\section{Paratype.-CTES-PB 12013, CTES-PMP 2434 a, b, c.}

Diagnosis.-Wood type (tracheid radial pitting) is araucarian (100\% of the contiguous pits are araucarioid). Pits are araucarioid, uniseriate, flattened, and circular; alternate biseriate, circular, and hexagonal; uniseriate, partially biseriate, alternate, circular, hexagonal-flattened; and opposite circular, hexagonal-flattened in a pair or several pairs (japonicum type); and triseriate and bitriseriate, alternate circular and hexagonal. Cross-fields are araucarioid, with 2-14, 20 pits, circular, with elliptical or sometimes circular apertures, whose frequency range is $6-8$ pits, arranged in disordered groups or crown-shaped or some in two or four horizontal rows. The rays are homogeneous, mostly uniseriate, and the height in number of cells is 1-16, 20.

Occurrence.-La Matilde Formation, Santa Cruz Province, Argentina (Middle Jurassic).

Description.-Fragments of logs found in situ of $1.5 \mathrm{~m}$ in diameter, with $1 \mathrm{~m}$ height preserved, and a fallen trunk with visible dimensions of $1.50 \mathrm{~m}$ in length and $60 \mathrm{~cm}$ in diameter were studied. These materials came from the southeastern border of Laguna del Carbón locality. The following description is based on specimen CTES-PB 12012, which consists of a fragment of secondary xylem, pycnoxyilic, with distinct growth rings. In TS, the tracheids of the early wood are rectangular-ovoidal and polygonal in the shape. Tracheids of the early wood have an average radial diameter of $47 \mu \mathrm{m}(36-60 \mu \mathrm{m})$ and tangential diameter of $37 \mu \mathrm{m}(24-52 \mu \mathrm{m})$. In the late wood, the tracheids have a tangential average diameter of $35 \mu \mathrm{m}(24-40 \mu \mathrm{m})$ and radial diameter of $21 \mu \mathrm{m}(16-28 \mu \mathrm{m})$. The average number of tracheids that separate the rays is $7-8$, varying between $2-18$ tracheids. The rays are presented in a continuous way through the section (Fig. 7.1). In RLS, the wood type (tracheid radial pitting) is araucarian (100\% of the contiguous pits are araucarioid). Pits are araucarioid, uniseriate (9.6\% [7-12\%]), flattened (2.6\% [1-4\%]), and circular (7\% [6-9\%]); alternate biseriate (44.6\% [39-51\%]), circular (32.6\% [29-36\%]), and hexagonal (12\% [10-15\%]); uniseriate partially biseriate (37\% [36-38\%]), alternate, circular (22\% [21-24\%]), hexagonal-flattened (6\% [5-8\%]), and opposite circular (2\% [1-3\%]), hexagonal-flattened in a pair (4\% [3-5\%]) or in several pairs (japonicum type) (3\% [2-4\%]); and triseriate and bi-triseriate, alternate circular (1\% [1-2\%]) and hexagonal (6\% [5-8\%]). The size of the pits is $12-16 \mu \mathrm{m}$ and $20 \mu \mathrm{m} \mathrm{x}$ $10 \mu \mathrm{m}$. The pits present a circular aperture, which measures 4-6 $\mu \mathrm{m}$ (Figs. 7.2-7.5, 8.1-8.4). Cross-fields are araucarioid, having 2-14, 20 pits that are circular, with an elliptical or sometimes circular aperture, whose frequency range is 6-8 pits, arranged in disordered groups or crown-shaped or some in two or four horizontal rows. The pits measure $8-10 \mu \mathrm{m}$ and the apertures are elliptical measuring from $4-8 \mu \mathrm{m} \times 3 \mu \mathrm{m}$ or circular and 2.5-4 $\mu \mathrm{m}$ (Figs. 7.5-7.7, 8.1-8.5). The rays are homogeneous and most uniseriate, the height in number of cells is $1-16,20$, the average is 6 cells. The cells at both ends are elliptical and the centers are rectangular or quadrangular, measuring $15-52 \mu \mathrm{m}$ high x 15-30 $\mu \mathrm{m}$ wide (Fig.7.8).

Etymology.-In reference to Santa Cruz province, Argentina, where the analyzed wood was found. 
Table 4. Comparison between some species of Agathoxylon/Araucarioxylon from Gondwana sharing the characters: presence of circular pits (some flattened) and alternate (opposite) in the radial walls of the tracheids. (1/2: rays uniseriate partially biseriate; in parentheses $=$ character with occasional condition).

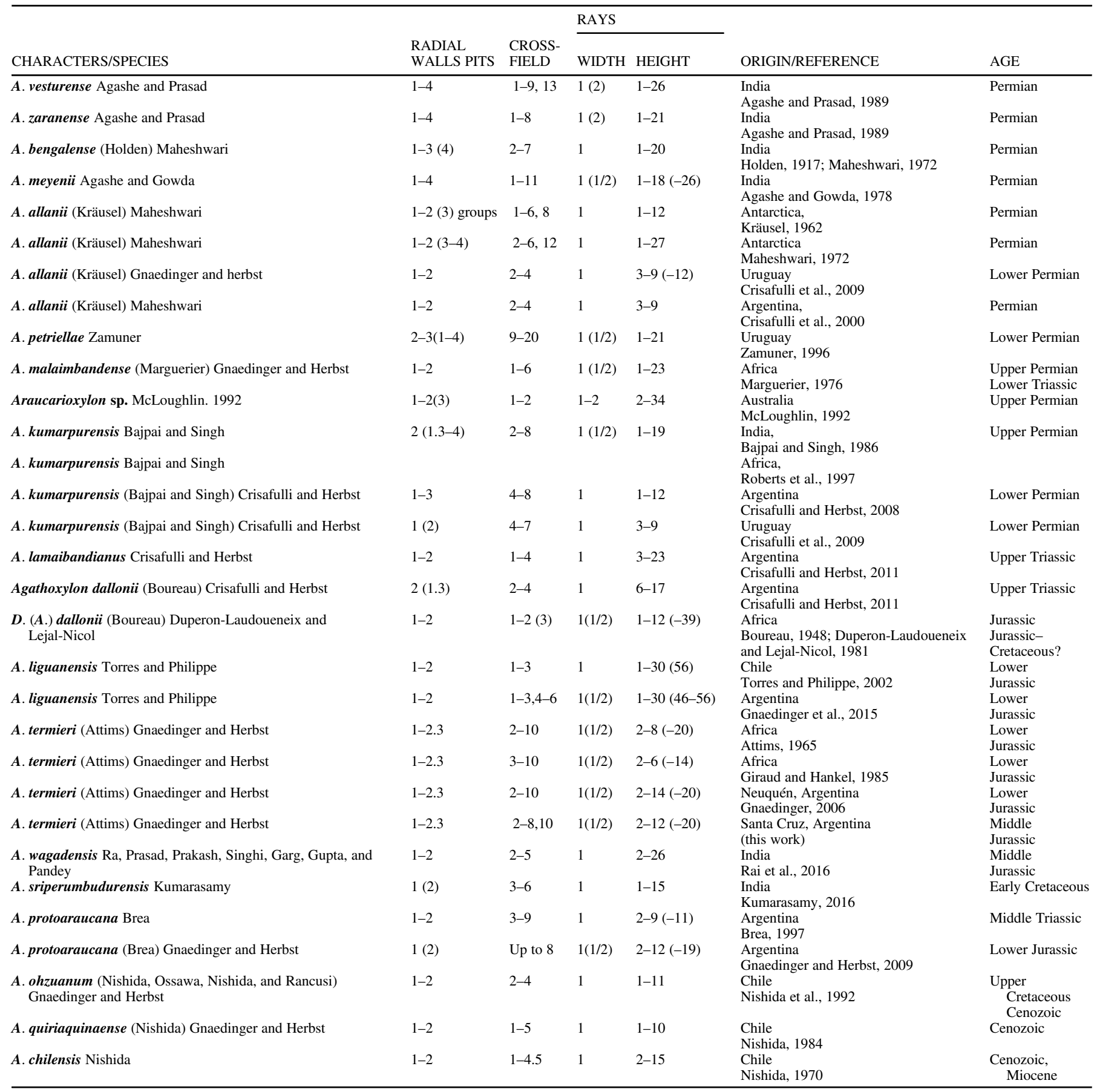

Remarks.-The comparisons made with the species of Agathoxylon described for Gondwana justify assignment of the La Matilde Formation specimens to a new species. In Table 5, comparisons made between species of Agathoxylon, Dadoxylon, and Araucarioxylon of Gondwana show that they share the following diagnostic characters: presence of circular, hexagonal, and flattened radial pitting.

The new species is distinguished from the other Gondwanan species by the arrangement of the tracheid pits, the number of pits in the cross-field, and by the height of the rays (Table 5). The most closely comparable species is Agathoxylon semibiseriatum
(Pant and Singh, 1987) Leiva Verón and Crisafulli in Leiva Verón et al., 2012 in most of the anatomical characters (Table 5), but there are differences in the radial pitting and rays.

\section{Qualitative and quantitative analysis of anatomical characters}

Tables 1 and 2 compare the four species of Agathoxylon identified from the La Matilde Formation, Santa Cruz, Argentina. The anatomical characters must be taken into account for the 

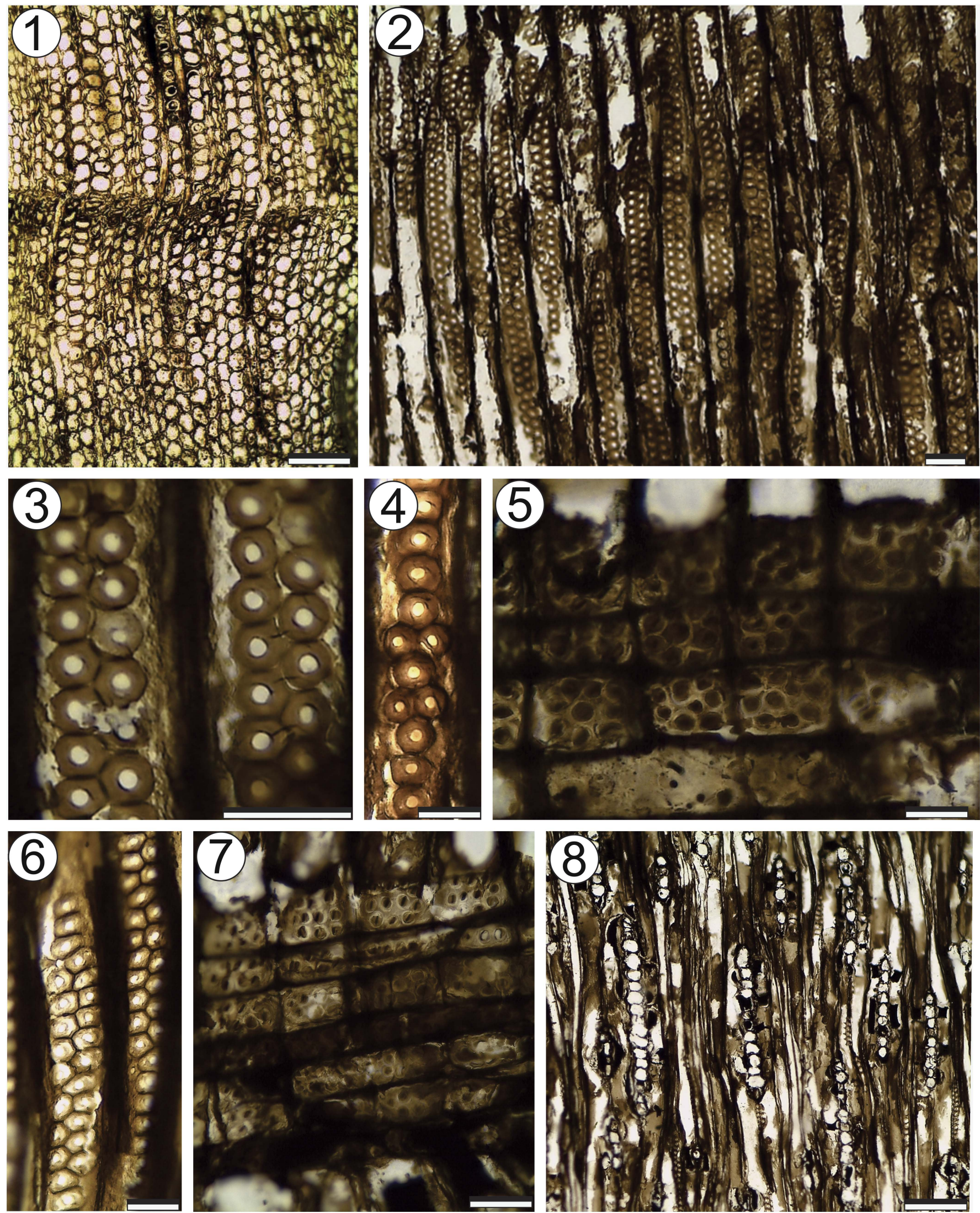

Figure 7. Agathoxylon santacruzense n. sp. (1) TS, detail of the tracheids and growth ring; $(\mathbf{2 - 4 , 6 ) ~ R L S , ~ p i t s ~ o n ~ t r a c h e i d ~ r a d i a l ~ w a l l s ; ~}(\mathbf{5}, \mathbf{7}) \mathrm{RLS}$, detail of cross-field pits; (8) TLS, rays. Scale bars: $(\mathbf{1})=190 \mu \mathrm{m} ;(\mathbf{2}-\mathbf{7})=45 \mu \mathrm{m} ;(\mathbf{8})=130 \mu \mathrm{m}$. CTES PB 12012. 

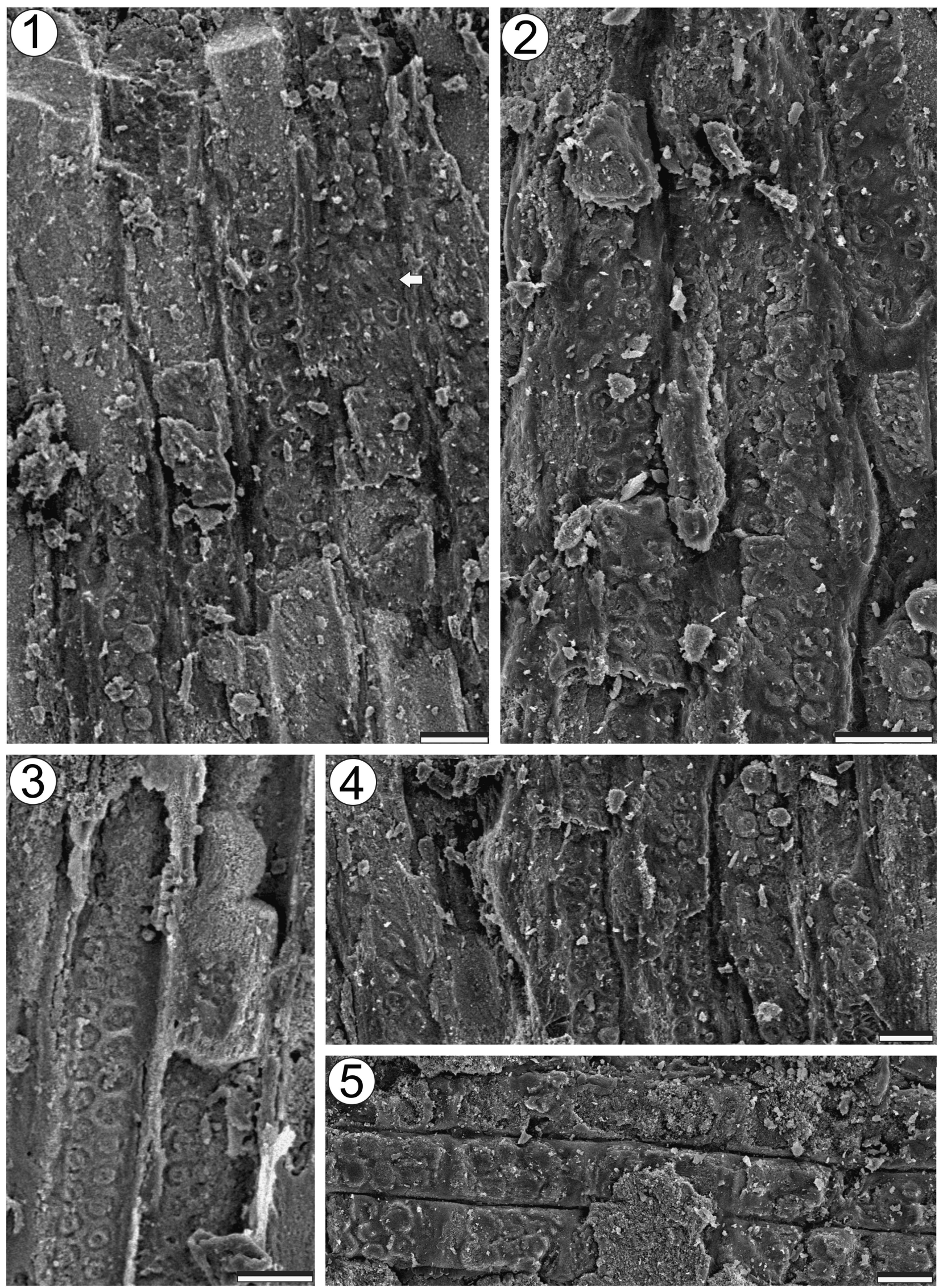

Figure 8. Agathoxylon santacruzense n. sp. (1-4) RLS, pits on tracheid radial walls; $(\mathbf{1}, \mathbf{5})$ RLS, detail of cross-field pits (arrow). Scale bars $=45 \mu \mathrm{m}$. CTES PB 12012 . 


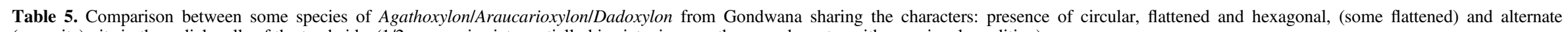
(opposite) pits in the radial walls of the tracheids. (1/2: rays uniseriate partially biseriate; in parentheses = character with occasional condition).

\begin{tabular}{|c|c|c|c|c|c|c|c|}
\hline \multirow[b]{2}{*}{ CHARACTERS/SPECIES } & \multicolumn{2}{|c|}{ RADIAL WALLS PITS } & \multirow[b]{2}{*}{$\begin{array}{l}\text { CROSS } \\
\text { FIELD }\end{array}$} & \multicolumn{2}{|l|}{ RAYS } & \multirow[b]{2}{*}{$\begin{array}{l}\text { ORIGIN } \\
\text { REFERENCE }\end{array}$} & \multirow[b]{2}{*}{ AGE } \\
\hline & SERIATION & DISPOSITION & & Width & Height & & \\
\hline A. loharense Agashe and Gowda & $1-3(4)$ & Contiguous (separated) Alternate, opposite & $1-9$ & $2(1)$ & $2-27$ & $\begin{array}{l}\text { India } \\
\text { Agashe and Gowda, } 1978\end{array}$ & Permian \\
\hline A.surangei Agashe, Prasad and Suresh & $1-4$ & Contiguous (separate) Alternate & $1-11$ & $1-2$ & $1-35$ & Agashe et al., 1981 & Permian \\
\hline A. lathiense Agashe, Prasad and Suresh & $1-4$ & Contiguous (separate) Alternate (opposite) in groups of 2,3 , or more & $1-10$ & 1 & $1-27$ & $\begin{array}{l}\text { India } \\
\text { Agashe et al., } 1981\end{array}$ & Permian \\
\hline A. bradshaawianum Bajpai and Maheshwari & $1-5$ & Contiguous, alternate & $2-4$ & $1(1 / 2)$ & - & $\begin{array}{l}\text { India } \\
\text { Bajpai and Maheshwari, } 1986\end{array}$ & Permian \\
\hline A. bhivkundense Agashe and Prasad & $1-2$ & Contiguous (separate) Alternate (opposite) in groups of 2, 3, or 4 & $1-8$ & $1-2$ & $1-33$ & $\begin{array}{l}\text { India } \\
\text { Agashe and Prasad, } 1989\end{array}$ & Permian \\
\hline A. parbeliense (Rao) Maheshwari & $1-5$ & Contiguous, alternate & $8-9$ & 1 & $1-24$ & $\begin{array}{l}\text { India } \\
\text { Rao, } 1935\end{array}$ & Permian \\
\hline A. kothariensis Agashe and Prasad & $1-4$ & Contiguous (separate) Alternate (opposite) groups of 2-8 & $1-12$ & $1-3$ & $1-44$ & $\begin{array}{l}\text { India } \\
\text { Agashe and Prasad, } 1989\end{array}$ & Permian \\
\hline A. sp. cf. A. ningahense Maheshwari & $2-3(1-4)$ & Separate, contiguous, alternate & $2-6(10)$ & $1(1 / 2)$ & $1-9$ & $\begin{array}{l}\text { Antarctica } \\
\text { Maheshwari, } 1972\end{array}$ & $\begin{array}{l}\text { Lower } \\
\text { Permian }\end{array}$ \\
\hline A. gondwanense (Maithy) Maheshwari & $3-4(1-2.5)$ & Contiguous, alternate or subopposite & $2-8$ & $1(1 / 2)$ & $1-43$ & $\begin{array}{l}\text { India } \\
\text { Maithy, } 1964\end{array}$ & $\begin{array}{l}\text { Lower } \\
\text { Permian }\end{array}$ \\
\hline Araucarioxylon semibiseriatum Pant and Singh & $1-4(5)$ & Contiguous, separate, subopposite, alternate & $4-6,12$ & $1(1 / 2)$ & $1-24,38$ & $\begin{array}{l}\text { India } \\
\text { Pant and Sing, } 1987\end{array}$ & Permian \\
\hline A. kharkhariense (Maithy) Maheshwari & $1-3$, groups & Contiguous, alternate subopposite or opposite & $2-5,7$ & $1(1 / 2)$ & $1-29$ & $\begin{array}{l}\text { India } \\
\text { Maithy, } 1964\end{array}$ & $\begin{array}{l}\text { Lower } \\
\text { Permian }\end{array}$ \\
\hline A. kharkhariense (Maithy) Maheshwari & $1-3$, groups & Contiguous, alternate or opposite & $3-8$ & 1 & $2-20$ & $\begin{array}{l}\text { Argentina } \\
\text { Crisafulli et al., } 2000\end{array}$ & $\begin{array}{l}\text { Lower } \\
\text { Permian }\end{array}$ \\
\hline D. nicoli Seward & $1-4$ & Contiguous, alternate & - & $1-2$ & $2-17$ & $\begin{array}{l}\text { Australia } \\
\text { McLoughlin, } 1992\end{array}$ & Upper Permian \\
\hline Araucarioxylon semibiseriatum Pant and Singh & $1-2$ & Contiguous, opposite, alternate & $9(11)$ & $1(1 / 2)$ & $5-11(16)$ & $\begin{array}{l}\text { Chile } \\
\text { Lutz et al., } 2001\end{array}$ & Upper Triassic \\
\hline $\begin{array}{l}\text { Agathoxylon semibiseriatum (Pant and Singh) } \\
\text { Leiva Verón and Crisafulli in Leiva Verón et al. }\end{array}$ & $1-2(3)$ & Contiguous, subopposite, alternate & $6-9$ & $1(1 / 2)$ & $1-14$ & $\begin{array}{l}\text { Paraguay } \\
\text { Leiva Verón et al., } 2012\end{array}$ & Upper Permian \\
\hline A. matildense Zamuner and Falaschi & $1(1 / 2)$ & $\begin{array}{l}\text { Contiguous } \\
\text { Alternate }\end{array}$ & $4-5$ & 1 & $1-4$ & $\begin{array}{l}\text { Santa Cruz, Argentina } \\
\text { Zamuner and Falaschi, } 2005\end{array}$ & Middle Jurassic \\
\hline D. rajmahalense Sahni (in Suryanarayana 1955) & $1(2-3)$ & $\begin{array}{l}\text { Alternate (opposite) contiguous and separate; flattened } \\
\text { and rarely circular, hexagonal }\end{array}$ & - & 1 & $1-12,20$ & $\begin{array}{l}\text { India } \\
\text { Suryanarayana, } 1956\end{array}$ & Middle Jurassic \\
\hline A. pranhitaensis Rajanikanth and Sukh-Dev & 1 (2) & Contiguous, alternate & $2-4,6$ & $1(1 / 2)$ & $1-10$ & $\begin{array}{l}\text { India } \\
\text { Rajanikanth and Sukh-Dev, } 1989\end{array}$ & Middle Jurassic \\
\hline Agathoxylon santacruzense $\mathrm{n}$. sp. & $\begin{array}{l}\text { 1-seriate }(29 \%) \\
\text { 2-seriate }(63.5 \%) \\
\text { 3-seriate }(7.5 \%)\end{array}$ & $\begin{array}{l}\text { Contiguous (100\%) } \\
\text { Separate }(2 \%) \\
\text { Alternate }(92 \%) \\
\text { Opposite }(8 \%)\end{array}$ & 2-14 (20) & 1 & $1-16,20$ & $\begin{array}{l}\text { Argentina } \\
\text { (This work) }\end{array}$ & Middle Jurassic \\
\hline D. (Araucarioxylon) rajmahalense Sahni & $\begin{array}{l}\text { EW: } 2-3(1-3) \\
\text { LW: } 1\end{array}$ & $\begin{array}{l}\text { EW: alternate, hexagonal (circular ). } \\
\text { LW: contiguous and flattened pits (circular, separate). }\end{array}$ & - & 1 & $1-20$ & $\begin{array}{l}\text { India } \\
\text { Sahni, } 1931\end{array}$ & $\begin{array}{l}\text { Lower } \\
\text { Cretaceous }\end{array}$ \\
\hline Agathoxylon sp. Ottone and Medina & $1-2$ & Alternate & $1-4$ & $1(1 / 2)$ & $1-25$ & $\begin{array}{l}\text { Antarctica } \\
\text { Ottone and Medina, } 1998\end{array}$ & Lower Cretaceous \\
\hline A. sp. Falcon-Lang and Cantrill & $\begin{array}{l}\text { 1-seriate }(23 \%) \\
\text { 2-seriate }(76 \%) \\
3 \text {-seriate }(1 \%)\end{array}$ & $\begin{array}{l}\text { Contiguous (98\%) } \\
\text { Separate }(2 \%) \\
\text { Alternate }(98.5 \%) \\
\text { Opposite }(1.5 \%)\end{array}$ & $1-4$ & 1 & $1-11$ & $\begin{array}{l}\text { Antarctica } \\
\text { Falcon-Lang and Cantrill, } 2000\end{array}$ & $\begin{array}{l}\text { Upper Cretaceous } \\
\text { (Albian) }\end{array}$ \\
\hline A. chapmanae Poole and Cantrill & $\begin{array}{l}\text { 1-seriate }(21 \%) \\
\text { 2-seriate }(74 \%) \\
\text { 3-seriate }(5 \%)\end{array}$ & Contiguous, alternate & $2-11$ & 1 & $1-25$ & $\begin{array}{l}\text { Antarctica } \\
\text { Poole and Cantrill, } 2001\end{array}$ & Upper Cretaceous \\
\hline A. eocenum (Chitaley) Trivedi and Srivastava & $2(1-3)$ & Contiguous, (separate), alternate (opposite) Groups irregular & $1-7$ & $1(1 / 2)$ & $1-15$ & $\begin{array}{l}\text { India } \\
\text { Chitaley, 1949; Trivedi and } \\
\text { Srivastava, } 1989\end{array}$ & Tertiary \\
\hline A. deccani (Shukla) Trivedi and Srivastava & $1-2$ & Contiguous, alternate (opposite) & $1-6$ & $1(2)$ & $2-49$ & $\begin{array}{l}\text { India } \\
\text { Shukla, 1938; Trivedi and } \\
\text { Srivastava, } 1989\end{array}$ & Tertiary \\
\hline
\end{tabular}


diagnosis of each species. Therefore, the differences between these species are mainly due to the seriation and different combinations of the tracheid radial wall pits; the type, number, and arrangement of the pits in the cross-fields and seriation; and height of the rays. Numerical differences between specimens of the same species, particularly in the seriationcombination percentages of the radial pitting, could be explained as intraspecific variation (Giraud and Hankel, 1985), as well as the degree of preservation of the specimen or of the portion in the early wood (at the beginning or at the end) where the data were obtained.

Anatomical characteristics of the woods were quantified in accordance with criteria proposed by Falcon-Lang and Cantrill (2000), Poole and Cantrill (2001), Gnaedinger (2012), and Gnaedinger et al. (2015). The following features were quantified: in RLS: (1) the nature of the bordered pitting on the tracheid walls ( $\mathrm{a}-$ percentages of uniseriate, biseriate, and triseriate pitted tracheids; $\mathrm{b}$-percentages of circular, flattened, and hexagonal-shape pitted tracheids; c-percentages of alternately or oppositely arranged multiseriate pits); (2) the mean, minimamaxima, occasional maximum, and frequency range of pits in the cross-fields (in terms of most common number of pits per cross-field); and in TLS, ray height (in terms of number of cells high) was also recorded in terms of minima-maxima, occasional maximum, and means (Table 2).

Plotted dispersion graphics based on quantitative data for each specimen (Fig. 9) clearly reflect the differences between identified species where these species plot as single continuous entities in "morphology space" (Falcon-Lang and Cantrill, 2000, 2001). Thus, four species with an araucarian secondary wood structure can be distinguished by their different percentages of tracheid radial pitting shapes and distribution (seriation), as well as by the range and mean number of pits in the cross-fields (Fig. 9). Figure 9.1 shows A. santalense and A. santacruzense $\mathrm{n}$. $\mathrm{sp}$. are grouped in the same "morphology space," that is, they have similar percentages of uniseriate and biseriate pits, while in the other comparisons (e.g., uniseriate pits versus hexagonal shape, biseriate pits versus opposite pits, and uniseriate pits versus cross-fields), the species clearly differ from the other taxa (Fig. 9.2-9.4).

Thus, A. agathioides (Kräusel and Jain) n. comb. and A. santalense (Sah and Jain) n. comb. are identified by a series of 1-3 pits and their combinations of flattened-hexagonal pits, with
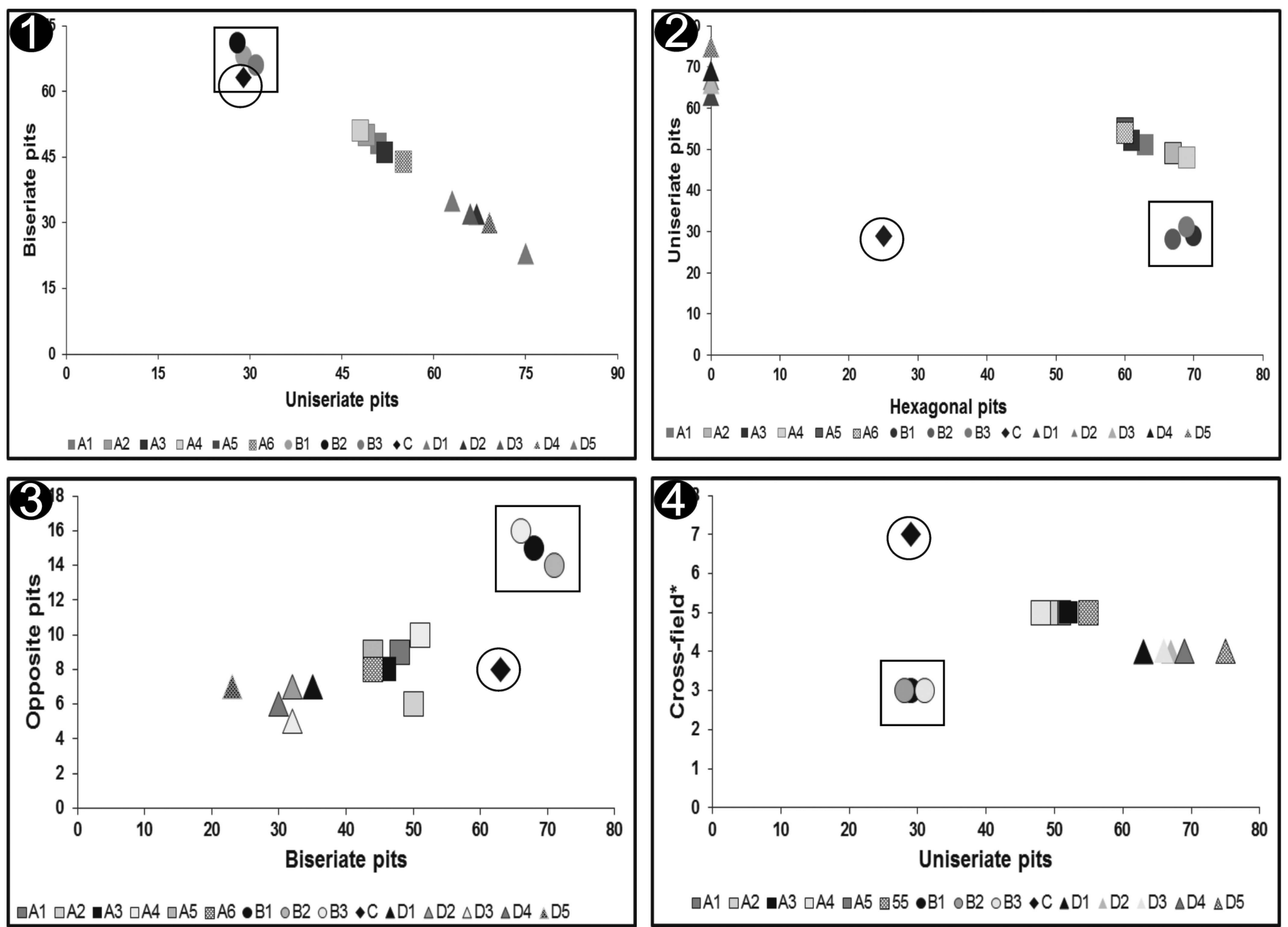

Figure 9. Plotted dispersion graphics based on quantitative data for specimen of the La Matilde Formation. Agathoxylon agathioides A1=CTES-PB 10659; $\mathrm{A} 2=\mathrm{CTES}-\mathrm{PB} 10647$; A3 = CTES-PB 14236; A4=CTES-PB 10703; A5 =CTES-PB 10702; A6=CTES-PB 12036; Agathoxylon santalense $\mathrm{B} 1=\mathrm{CTES}-\mathrm{PB}$ 10649; B2 = CTES-PB 14239; B3 =CTES-PB 10665; Agathoxylon termieri $\mathrm{C} 1=\mathrm{CTES}-\mathrm{PB}$ 10693; C2 =CTES-PB 10696; C3 = CTES-PB 10675; C4=CTESPB 12043; C5 = CTES-PB 12041; Agathoxylon santacruzense D = CTES-PB 12012. 

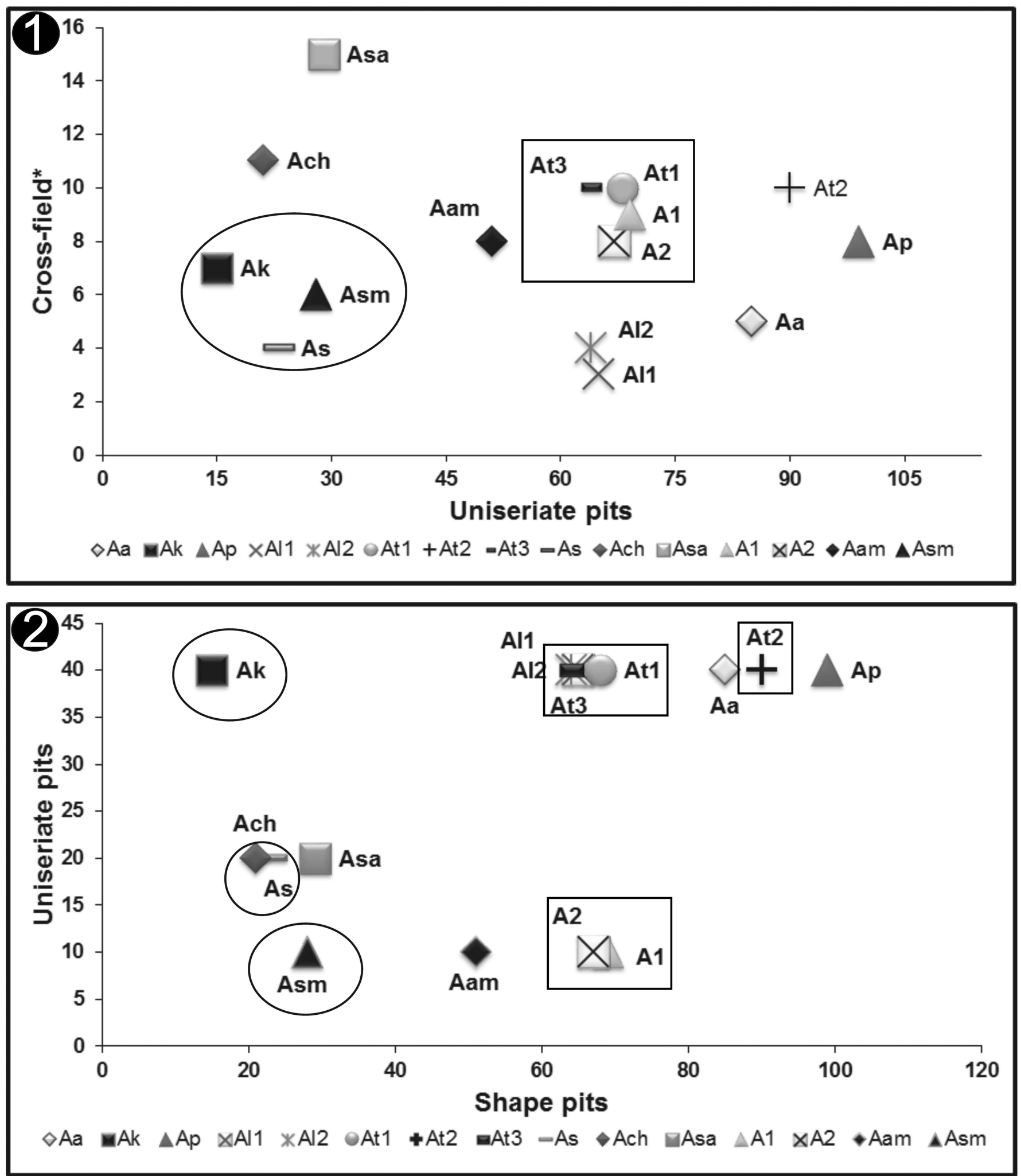

Figure 10. Plotted dispersion graphics based on Agathoxylon from La Matilde Formation and from the Gondwana. Aa=Agathoxylon africanum; Ak =A. karooensis; $\mathrm{Ap}=$ A. protoaraucana; $\mathrm{Al}=$ Agathoxylon liguaensis: $\mathrm{Al} 1=$ Chile, $\mathrm{Al} 2=$ Argentina; $\mathrm{At}=A$. termieri $: \mathrm{At} 1=\mathrm{Attims}, 1965 ; \mathrm{At} 2=\mathrm{Giraud}$ and Hankel, $1985 ; \mathrm{At} 3=$ this work; As =Araucarioxylon sp. (Falcon-Lang and Cantrill, 2000); Ach =A. chapmanae Poole and Cantrill, 2001; Asa=A. santalense (this work); A1=Araucarioxylon sp. 1; A2 = Araucarioxylon sp. 2 (Falcon-Lang and Cantrill, 2001); Aam =A. agathioides; Asm =A. santacruzense (this work). $*=$ mean value.

a predominance of a series of $1-2$ pits, as well as by the presence of groups of pits in the first species, while in the second, biseriate radial pitting predominates. In contrast, Agathoxylon termieri
(Attims) Gnaedinger and Herbst is defined by a series of $1-3$ pits and its different combinations of circular pits, with a predominance of uniseriate pits, and A. santacruzense $\mathrm{n}$. sp. is well defined by a 
series of 1-3 pits and its different combinations of circular, hexagonal, and flattened pit shapes (Fig. 9).

In Figure 10, the dispersion graphics compare species of the genus Agathoxylon using data obtained from the specimens analyzed in this contribution (Tables 1,2) and from the literature. For this reason, in this study, data such as uniseriate pits, shape of the pits, and maximum number of pits in the cross-fields were collected from the following Agathoxylon species: A. africanum (Bamford) Kurzawe and Merlotti (Permo-Triassic, JurassicCretaceous?) and A. karooensis (Bamford) Kurzawe and Merlotti (Permian and Cretaceous?) from South Africa (Bamford, 2000); A. protoaraucana (Triassic-Lower Jurassic) of Argentina (Gnaedinger and Herbst, 2009); A. liguaensis Torres and Philippe of the Lower Jurassic of Chile (Torres and Philippe, 2002) and Argentina (Gnaedinger et al., 2015); Dadoxylon (A.) termieri (Attims, 1965; Giraud and Hankel, 1985) of the Lower Jurassic of Africa; Cretaceous species described by Falcon-Lang and Cantrill (2000, 2001); and A. chapmanae of Poole and Cantrill (2001).

In Figure 10, the differences between fossil species are clearly observed; only two groups of taxa occupy the same "morphology space": (1) A. karooensis, Araucarioxylon sp. (Falcon-Lang and Cantrill, 2000), and the Patagonia specimens identified as A. santalense; and (2) A. termieri, Araucarioxylon sp. 1 (Falcon-Lang and Cantrill, 2001), and Araucarioxylon sp. 2 (Falcon-Lang and Cantrill, 2001), when comparing characters like percentage of uniseriate pits versus maximum number of cross-field pits (Fig. 10.1). When looking at anatomical characters, such as uniseriate pits versus the shape of the pits, the groups of species mentioned are distinguished from each other, occupying different spaces in the above-mentioned graph (Fig. 10.2).

The results obtained show that not only is the number of pits in the cross-field a diagnostic character, but also the shape of the radial pits (IAWA Committee, Richter et al., 2004). These parameters cannot only be used to discriminate genera and species of wood found in the same Formation, but also to establish differences/ similarities between other taxa described in other Formations.

\section{Conclusions}

This paper describes four coniferous wood taxa from the La Matilde Formation, clearly differentiated on the basis of their qualitative and quantitative anatomical parameters, that can be distinguished by their different percentages of tracheid radial pitting shapes and distribution (seriation) as well as by the range and mean number of pits in the cross-fields. This study contributes to the method proposed by Falcon-Lang and Cantrill (2000) because these parameters can be used to discriminate species of wood found in the same formation and between other taxa described in other formations.

The findings in the La Matilde Formation of leaves and branch impressions and silicified seed and pollen cones indicate that the "Jaramillo Petrified Forest" was mainly composed of Coniferales belonging to the families Araucariaceae, Podocarpaceae, and? Taxodiaceae. According to the xylological analysis carried out in this study, the presence of the family Araucariaceae in the forests of the La Matilde Formation is corroborated.
Agathoxylon is cosmopolitan, but the species A. agathioides and $A$. santalense have been previously described from the Upper Jurassic-Lower Cretaceous of the Rajmahal Hills, Bihar, India (Sah and Jain, 1964; Kraüsel and Jain, 1964), while A. termieri was described from the Lower Jurassic of Africa (Attims, 1965; Giraud and Hankel, 1985) and Argentina (Gnaedinger, 2006).

Based on the analysis of 250 specimens carried out so far, in eight localities of the Gran Bajo de San Julián sector, and through data on the distribution of the in situ logs obtained from the census carried out in the forests, the Agathoxylon taxa described here presents a different floristic distribution in the $\mathrm{La}$ Matilde Formation. Agathoxylon agathioides and A. santalense together with Taxodioxylon Gothan and Prototaxoxylon intertrappeum Prakash and Srivastava species are found in the top of the sedimentary sequence that appears in the Barda Blanca and Cerro Conito localities, and in the NW Laguna La Guadalosa outcrop from Gran Bajo de San Julián sector and Bajo El Puma locality of the central and south-western sector (Gnaedinger and Herbst, 2006; Gnaedinger, 2007b). A gathoxylon termierii associated with fern stipes and Podocarpaceae wood (Podocarpoxylon feruglioi Gnaedinger; Circoporopitys herbstii Gnaedinger) was identified in the base of the sedimentary sequence, near the carbonaceous levels in the Barda Blanca and Cerro Conito localities, as well as in the northern part of the Estancia Meseta Chica locality (Gnaedinger, 2007b).

Finally, A. santacruzense n. sp. with Circoporoxylon austroamericanum Gnaedinger was found only in the southeastern border of Laguna del Carbón locality (Gnaedinger, 2007b). The distinction of the species through qualitative and quantitative analyses and according to the distribution of the specimens in the different localities and in some localities in different strata of the sedimentary sequence could be indicating diverse forests at different moments during the Jurassic of the Patagonia (Gnaedinger, work in preparation). In this way, it could indicate, according to the distribution of the in situ logs of the fossil species found in the Barda Blanca and Cerro Conito localities, that these taxa formed small forests, or local forests, or small forests within dense forest, which is a habitat coincident with the extant Araucariaceae.

\section{Acknowledgments}

This contribution was partially funded by the Secretaría General de Ciencia y Técnica, Universidad Nacional del Nordeste (SGCyT-UNNE.PI 2015, 2018, Q005, 2014) and the Consejo Nacional de Investigaciones Científica y Técnicas-CONICET (PIP 2014, 2016, No. 112201301 00317) in a grant conferred to SCG. The authors are grateful to Katarzyna Piper, Editorial Services (UK) for revision of the English grammar.

\section{References}

Agashe, S., and Gowda, P., 1978, Anatomical study of a gymnospermous wood from Lower Gondwana of Maharashtra: Phytomorphology, v. 28, p. 269-274.

Agashe, S., and Prasad, K., 1989, Studies in fossil gymnospermous woods, part 7. Six new species of Lower Gondwana (Permian) gymnospermous woods from Chandrapur District, Maharashtra State, India: Palaeontographica, v. 138 B, p. 71-102. 
Agashe, S., Prasad, K., and Suresh, F., 1981, Two new species Araucarioxylon surangei and Araucarioxylon lathiense of petrified woods from lower Gondwana strata: The Palaeobotanist, v. 28, p. 122-127.

Archangelsky, S., and De La Sota, R.E., 1962, Estudio anatómico de un estípite petrificado de "Osmundites" de edad Jurásica, procedente del Gran Bajo de San Julián, provincia de Santa Cruz: Ameghiniana, v. 2, p. $153-164$.

Attims, Y., 1965, Etude anatomique et paléogéographique de quelques bois jurassiques du Maroc: Notes Du Service Geologique Du Maroc, v. 24 p. 33-52

Baez, A.M., and Nicoli, L., 2003, Reconstruyendo la rana jurásica Notobratrachus degiustoi. XIX Jornadas Argentinas de Paleontología de Vertebrados: Resúmenes, p. 8.

Bajpai, U., and Maheshwari, H., 1986, On two new fossil woods from the Raniganj Formation with remarks on Zalesskioxylon zambesiensis from Mozambique: The Paleobotanist, v. 35, p. 39-47.

Bajpai, U., and Singh, V., 1986, Araucarioxylon kurmarpurensis, a new gimnospermous wood from the Upper Permian of West Bengal: The Palaeobotanist, v. 35 , p. 53-56

Baldoni, A., 1981, Tafofloras Jurásicas y Eocretácicas de América del Sur, in Volkheimer, W., and Musacchio, E.A., eds., Cuencas Sedimentarias del Jurásico y Cretácico de América del Sur: Buenos Aires, Special Publication, 2, p. 359-391.

Baldoni, A.M., 1990, Tafofloras del Jurásico Medio de la Patagonia Extraandina, in Volkheimer, W., ed., Bioestratigrafía de los Sistemas Regionales del Jurásico y Cretácico de America del Sur: Comité Sudamericano del Jurásico y Cretácico, Mendoza, v. 2, p. 313-353.

Bamford, M., 2000, Fossil woods of Karoo age deposits in South Africa and Namibia as an aid to biostratigraphical correlation: Journal of African Earth Sciences, v. 1, p. 119-132.

Bamford, M., and Philippe, M., 2001, Jurassic-Early Cretaceous Gondwanan homoxylous woods: a nomenclatural revision of the genera with taxonomic notes: Review of Palaeobotany and Palynology, v. 113 , p. 287-297.

Bertels, A., 1977, Estratigrafía y micropaleontología de la Formación San Julián en su área tipo, provincia de Santa Cruz: Ameghiniana, v. 14 p. 233-293.

Bhardwaj, D.C., 1953, Jurassic woods from the Rajmahal Hills Bihar: Palaeobotanist, v. 2, p. 59-70.

Billimoria, J.J., 1948, New species of Dadoxylon from C. P. Palaeobotany of India. VI: Journal of Indian Botanical Society, v. 26, p. 1-260.

Bose, M.N., and Maheshwari, H.K., 1974, Mesozoic conifers, in Surange, K.R., Lakhampal, R.N., and Bharadwaj, D.C., eds., Aspects and Appraisal of Indian Palaobotany: Lucknow, Birbal Sahni Institute of Palaeobotany, p. $21-223$.

Boureau, E., 1948, Etude paléoxylologique du Sahara. I. Presence du Dadoxylon (Araucarioxylon) dallonii n. sp: Bulletin du Muséum d'Histoire Naturelle, v. 20 , p. $420-426$.

Brea, M., 1997, Una nueva especie del Género Araucarioxylon Kraus 1870 , emend. Maheshwari 1972 del Triásico de Agua de la Zorra, Uspallata, Mendoza, Argentina: Ameghiniana, v. 34, p. 485-496.

Calder, M.G., 1953, A coniferous petrified forest in Patagonia: Bulletin British Museum (Natural History): Geology, v. 2, p. 99-138.

Chattaway, M., 1932, Proposed standard for numerical values used in describing woods: Tropical Woods, v. 59, p. 20-28.

Chitaley, S., 1949, On a new species of Dadoxylon, Dadoxylon eocenum sp. nov., from the District of Chhindwara, C.P., India: Journal of the Indian Botanical Society, v. 28, p. 227-236.

Criado Roque, P., 1953, Informe preliminar reconocimiento geológico zona Bahia Laura, Territorio de Santa Cruz: Yacimiento Petrolíferos Fiscales (inédito), p. 18

Crisafulli, A., 2001, Leños pérmicos de la Formación Yaguarí, Pérmico Superior de Uruguay: Amenghiniana, v. 38, p. 61-72.

Crisafulli, A., and Herbst, R., 2008, Maderas gimnospérmicas de la Formación Solca (Pérmico Inferior), Provincia de la Rioja, Argentina: Ameghiniana, v. 45 , p. $737-751$.

Crisafulli, A., and Herbst, R., 2011, La Flora Triásica del Grupo El Tranquilo, provincia de Santa Cruz (Patagonia): Leños Fósiles: Ameghiniana, v. 4 p. $275-288$

Crisafulli, A., and Lutz, A., 1997, Leños gimnospérmicos de la Formación Melo (Pérmico Inferior), Uruguay. Parte 1: Barakaroxylon Surange y Maihty, 1962 y Araucarioxylon Kraus, 1870: Ameghiniana, v. 34, p. 437-445.

Crisafulli, A., Lutz, A., and Melchor, R., 2000, Maderas gimnospérmicas de la Formación Carapacha (Pérmico), provincia de La Pampa, Argentina: Ameghiniana, v. 37, p. 181-191.

Crisafulli, A., Herbst, R., and Manza Stortti, L., 2009, Maderas gimnospérmicas de la Formación Tres Islas (Pérmico Inferior) de Uruguay: Gaea, v. 5, p. $1-14$.
De Barrios, R.E., 1989, Aspectos geológicos y geoquímicos de la Formación Chon Aike (Grupo Bahía Laura), Jurásico Medio a Superior, en el noroeste de la Provincia de Santa Cruz [PhD Thesis]: La Plata, Universidad Nacional de La Plata, 528 p.

De Barrios, R.E., 1993, El Volcanismo ácido Jurásico en el Noroeste de Santa Cruz, Argentina: Actas $12^{\text {th }}$ Congreso Geológico Argentino, v. 4, p. $189-198$.

De Barrios, R.E., Panza, J.L., and Nullo, F.E., 1999, Jurásico y Cretácico del Macizo del Deseado, provincia de Santa Cruz, in Caminos, R., ed., Geología Argentina. Servicio Geológico Minero Argentino: Anales Instituto de Geología y Recursos Minerales, v. 29, p. 511-527.

De Giusto, J.M., 1955, Informe geológico preliminar, zona San Julián: Buenos Aires, Yacimientos Petroliferos Físcales, $15 \mathrm{p}$.

De Giusto, J.M., Di Persia, C.A., and Pezzi, E., 1980, Nesocratón del Deseado, in Leanza, A.F., ed., Geología Regional Argentina: Academia Nacional de Ciencias de Córdoba, v. 2, p. 1389-1430.

Delhaes, G., 1913, Sobre la presencia del Rético en la costa patagónica: Dirección General de Minería y Geología, Boletín 1 Serie B, p. 5-10.

Duperon-Laudoueneix, M., and Lejal-Nicol, A., 1981, Sur deux bois homoxylés du Sud-Ouest de'l Égypte: Congrés nacional des Sociétés savantes, 106, Sect. Sciences, v. 1, p. 9-40.

Echeveste, H., Fernández, R., Bellieni, G., Tessone, M., Llambías, E., Schlamuk, I., Piccirillo, E., and De Min, A., 2001, Relaciones entre las Formaciones Bajo Pobre y Chon Aike (Jurásico Medio a Superior) en el área Estancia El Fénix-Cerro Huemul, zona centro-occidental del Macizo del Deseado, provincia de Santa Cruz: Revista Asociación Geológica Argentina, v. 56, p. 548-558.

Engler, A., 1897, Die naturlichen Pflanzenfamilien. Nachtrage zum 2-4 Teil: Leipzig, Engelmann, 198 p.

Erasmus, T., 1976, On the anatomy of Dadoxylon arberi Seward, with some remarks on the phylogenetical tendencies of its tracheid pits: Palaeontologia Africana, v. 19, p. 127-133.

Falcon-Lang, H.J., and Cantrill, D.J., 2000, Cretaceous (Late Albian) coniferales of Alexander Island, Antarctica 1. Wood taxonomy: a quantitative approach: Review of Palaeobotany and Palynology, v. 111, p. 1-17.

Falcon-Lang, H.J., and Cantrill, D.J., 2001, Gymnosperm woods from the Cretaceous (mid-Aptian) Cerro Negro Formation, Byers Peninsula, Livingston Island, Antarctica: the arborescent vegetation of a volcanic arc: Cretaceous Research, v. 22, p. 277-293.

Feruglio, E., 1949, Descripción Geológica de la Patagonia: Buenos Aires, Yacimientos Petrolíferos Fiscales, v. 1, p. 334

Feruglio, E., 1951, Piante del Mesozoico de la Patagonia: Publicación Instituto Geológico Universidad de Torino fasc. v. 1, p. 35-80.

Frenguelli, J., 1933, Situación estratigráfica y edad de la "Zona con Araucarias" al sur del curso inferior del río Deseado: Boletín de Informaciones Petroleras, año 10, v. 112, p. 843-900.

Gallego, O.F., 1994, Conchostrácos Jurásicos de Santa Cruz y Chubut, Argentina: Ameghiniana, v. 31, p. 333-345.

García Esteban, L., De Palacios, P., Guindeo Casasús, A., García Esteban, L., Lázaro Durán, I., González Fernández, L., Rodriguez Salvador, Y., Fernández García, S., Bobadilla Maldonado, I., and Camacho Atalaya, A., 2002, Anatomía e identificación de maderas de coníferas a nivel de especies: Madrid, Coedición Fundación Conde del Valle de Salazar: Ediciones Mundi-Prensa, $421 \mathrm{p}$.

García Esteban, L., Guindeo Casasús, A., Pereza Oramas, C., and de Palacios de Palacios, P., 2003, La madera y su anatomía: Madrid, Coedición Fundación Conde del Valle de Salazar: Ediciones Mundi-Prensa, 327 p.

Giraud, B., and Hankel, O., 1985, Bois fossiles des dépôts du Karoo du Bassin du Luwegu (Tanzanie méridionale): Annales de Paléontologie, v. 71, p. $159-185$.

Gnaedinger, S., 2000, Leños Gimnospérmicos de la Formación La Matilde, Gran Bajo de San Julián, provincia de Santa Cruz, Argentina: XI Simposio Argentino de Paleobotánica y Palinología: Tucumán, Resúmenes, p. 38.

Gnaedinger, S., 2006, Primer registro de maderas de la Formación Piedra Pintada (Jurásico Temprano), provincia de Neuquén, Argentina: Revista Museo Argentino de Ciencias Naturales, v. 8, p. 171-177.

Gnaedinger, S., 2007a, Planoxylon Stopes, Protelicoxylon Philippe y Herbstiloxylon n. gen. (Coniferales) de la Formación La Matilde (Jurásico Medio), Provincia de Santa Cruz, Argentina: Ameghiniana, v. 44, p. 321-335.

Gnaedinger, S., 2007b, Podocarpaceae woods (Coniferales) from middle Jurassic La Matilde Formation, Santa Cruz province, Argentina: Review of Palaeobotany and Palynology, v. 147, p. 77-93.

Gnaedinger, S., 2012, Ginkgoaleans woods from Middle Jurassic of the Argentina. Taxonomic considerations and palaeobiogeographical distribution: Geobios, v. 45, p. 187-198.

Gnaedinger, S., and Herbst, R., 2006, El género Prototaxoxylon Krausel y Dolianiti (Taxales) de la Formación La Matilde (Jurássico Médio), Gran Bajo de San Julián, Santa Cruz, Argentina: Amenghiniana, v. 43, p. $123-138$. 
Gnaedinger, S., and Herbst, R., 2009, Primer registro de maderas gimnospérmicas de La Formación Roca Blanca (Jurásico Inferior), provincia de Santa Cruz, Argentina: Ameghiniana, v. 4, p. 59-71.

Gnaedinger, S., García Massini, J.L., Bechis, F., and Zavattieri, A.M., 2015, Coniferous woods and wood-decaying fungi from the El Freno Formation (Lower Jurassic), Neuquén Basin, Mendoza Province, Argentina: Ameghiniana. v. 52, p. 447-467.

Greguss, P., 1955, Identification of Living Gymnosperms on the Basis of Xylotomy: Budapest, Akadémiai Kiado, 508 p.

Hartig, T., 1848, Beitrage zur Geschichte der Pflanzen un zur Kenntniss der Norddeutschen Braunko Flora: Botanische Zeitung, v. 6, p. 185-190.

Henkel, A., and Hochstetter, W., 1865, Synopsis der Nadelhölzer deren charakteristischen Merkmale nebst Andeutungen über ihre Cultur und Ausdauer in Deutschlands Klima: Stuttgart, J. G. Cottaschen Buchhandlung, $446 \mathrm{p}$.

Herbst, R., 1977, Dos nuevas sp. de Osmundacaulis (Osmundaceae, Filices) y otros restos de Osmundales de Argentina: Corrientes, Facena, v. 1, p. 19-40.

Herbst, R., 2003, Osmundacaulis tehuelchense n. sp. (Osmundaceae, Filices) from the Middle Jurassic of Santa Cruz province (Patagonia, Argentina): Courier Senckenberg Forschungs institute, v. 241, p. 85-95.

Herbst, R., and Salazar, E., 1999, Revisión de la flora Matildense del Gran Bajo de San Julián, Provincia de Santa Cruz, Argentina: Facena. v. 14, p. 7-24.

Herbst, R., Lutz, A., Gallego, O., and Acevedo, E., 1995, El bosque petrificado del Gran Bajo de San Julián, provincia de Santa Cruz (Resúmen): Ameghiniana, v. 32, p. 107

Holden, R., 1917, On the anatomy of two Palaeozoic stems from India: Annals of Botany, v. 31, p. 315-326.

Jeyasingh, D.E.P., and Kumarasamy, D., 1995, An unusual pycnoxylic wood from a new upper Gondwana locality in Tamil Nadu, India: Review of Palaeobotany and Palynology, v. 85, p. 341-350.

Jones, T.P., and Rowe, N.P., 1999, eds, Fossil Plants and Spores: Modern Techniques: Special Publication of the Geological Society of London, $396 \mathrm{p}$.

Kräusel, R., 1962, Appendix on Antartic fossil wood, in Plumstead, E.P., ed., Fossil Floras of Antartica: Trans-Antarctic Expedition, Scientific Reports 9, p. $133-140$

Kräusel, R., and Dolianiti, E., 1958, Gymnospermenhölzer aus dem Paläozoikum Brasiliens: Palaeontographica, v. 104 B, p. 115-137.

Kräusel, R., and Jain, K., 1964, New coniferous wood from the Rajmahal Hills, Bihar, India: The Palaeobotanist, v. 12, p. 59-67.

Kumarasamy, D., 2016, A new fossil conifer wood from the Sriperumbudur Formation, Tamil Nadu, India: International Journal of Geology and Earth Science, v. 2, issue 3, p. 28-32.

Lakhanpal, R.N., Prakash, U., and Bande, M.B., 1977, An Araucarian fossil wood from the Deccan Intertrappean beds of Mohgaon Kalan: The Palaeobotanist, v. 24, p. 125-131

Leiva Verón, V., Crisafulli, A., Herbst, R., Filippi, V., and Molina, S., 2012 Guavirá, una nueva localidad con maderas fósiles de la Formación Tacuary (Pérmico Superior) de Paraguay: Gaea_Journal of Geoscience, v. 8, n. 2, p. 67-81.

Lucas, R.C., and Lacey, W.S., 1981, A permineralized wood flora of probable Cenozoic age from King George Island, South Shetland Island: British Antarctic Survey Bulletin, v. 53, p. 147-151.

Lutz, A., Cisafulli., A., and Herbst, R., 2001, Contribución al estudio xiloflorístico de la Formación La Ternera, Triásico Superior (Chile): Ameghiniana, v. 38, p. 119-127.

Maheshwari, H.K., 1964, Studies in Glossopteris flora of India-16 Dadoxylon jamudhiense - a new species of fossil wood from the Raniganj stage of Jharia coalfield, Bihm: Palaeobotanist, v. 12, p. 267-269.

Maheshwari, H.K., 1972, Permian wood from Antarctica and revision of some Lower Gondwana wood taxa: Palaeontographica, v. 203 B, p. 1-82.

Maithy, P., 1964, Two new species of Dadoxylon from the Lower Gondwana of India: Studies in the Glossopteris flora of India: The Paleobotanist, v. 13, p. 89-93.

Maniero, J., 1946, Uma nova madeira fóssil do Brasil Meridional, Dadoxylon roxoi sp. n: Revista do Instituto Adolfo Lutz, v. 6, p. 65-76.

Marguerier, J., 1976, Paleoxylologie du Karoo Malgache. Étude d'un bois fossile de la sakamena (District de Mahabo) Dadoxylon (Araucarioxylon) malaimbandense $\mathrm{n}$. sp: Actes du 97ème Congrés National des Societés Savantes (Nantes), p. 87-105

Mazzoni, M.M., Spalletti, L.A., Iñiguez Rodriguez, A.M., and Teruggi, M., 1981, El Grupo Bahía Laura en el Gran Bajo de San Julián, Provincia de Santa Cruz: ${ }^{\text {th }}$ Congreso Geológico Argentino, Actas, v. 3, p. 485-507.

McLoughlin, S., 1992, Late Permian megafossils from the Bowen Basin, Queensland, Australia: Part 1: Palaeontographica, v. 228 B, p. 105-149.

Menéndez, C., 1960, Cono masculino de una conífera fósil del Bosque Petrificado de Santa Cruz: Ameghiniana, v. 2, p. 11-20.
Morton, S., and Herbst, R., 2001, Nuevas especies del género Diplodon Spix (Bivalvia, Unionidea) del Jurásico Medio (Formación La Matilde), Provincia de Santa Cruz, Argentina: Revista Museo Argentino Ciencias Naturales, v. 3, p. 159-164.

Nishida, M., 1970, On some fossil plants from Chile, South. America: Annual Report of the Foreign Students' College of Chiba University, v. 5, p. $13-18$.

Nishida, M., 1984, The anatomy and affinities of the petrified plants from the Cenozoic of Chile. IV. Dicotyledonous woods from Quiriquina island, near Concepción, in M. Nishida, M., ed., Contributions to the Botany in the Andes I: Tokyo, Academia Scientific Book Inc, p. 111-121.

Nishida, M., Ohsawa, T., Nishida, H., and Rancusi, H. M., 1992, Permineralized coniferous woods from the XI Region of Chile, Central Patagonia: Research Institute of Evolutionary Biology, Science Report, v. 7, p. 47-59.

Ottone, E.G., and Medina, F.A., 1998, A wood from the Early Cretaceous of James Ross Island, Antarctica: Ameghiniana, v. 35, p. 291-298.

Pant, D.D., and Singh, V.K., 1987, Xylotomy of some woods from Raniganj Formation (Permian), Raniganj Coalfield, India: Palaeontographica, v. 203 B, p. $1-82$.

Panza, J.L., 1982, Descripción geológica de las Hojas 53e "Gobernador Moyano" y 54e "Cerro Vanguardia": Servicio Geológico Nacional (inédito), $197 \mathrm{p}$.

Panza, J.L., 1984, Descripción geológica de las Hojas 54f "Bajo de la Leona" y 54g "Bahia Laura", pcia, de Santa Cruz: Servicio Geológico Nacional (inédito), $170 \mathrm{p}$

Panza, J.L., 1986, Descripción geológica de la Hoja 54d "La Manchuria", Provincia de Santa Cruz: Buenos Aires, Servicio Geológico Nacional (inédito), $141 \mathrm{p}$.

Panza, J.L., 1995, Hoja Geológica 4966-I-II Bahía Laura, escala 1:250.000, Provincia de Santa Cruz: Dirección Nacional del Servicio Geológico, Boletín, v. 214, p. 1-84.

Panza, J.L., 1998, Hoja Geológica 4769-IV Monumento Nacional Bosques Petrificados, escala 1:250.000: Santa Cruz, Servicio Geológico Minero Argentino, Boletín, 257 (unedited).

Panza, J.L., and Cobos, J.C., 1998, Hoja geológica 4769-III Destacamento La Marí, escala 1:250.000: Santa Cruz, Servicio Geológico Minero Argentino (inédito).

Panza, J.L., and De Barrios, R., 1989, Descripción geológica de las Hojas $56 f$ "Cordón Alto" y 56g "Puerto San Julián", Provincia de Santa Cruz: Servicio Geológico Nacional, (inédito), $155 \mathrm{p}$.

Panza, J.L., and Irigoyen, M.V., 1995, Hoja Geológica 4969-IV Puerto San Julián, escala 1:250.000, Provincia de Santa Cruz: Dirección Nacional Servicio Geológico, Boletín, v. 211, p. 1-78.

Panza, J.L., and Marín, G., 1996, Hoja Geológica 4969-1 Gobernador Gregores, escala 1:250.000, Provincia de Santa Cruz: Dirección Nacional del Servicio Geológico, Boletín, v. 239, p. 1-104.

Philippe, M., and Bamford, M.K., 2008, A key to morphogenera used for Mesozoic conifer-like woods: Review of Palaeobotany and Palynology, v. 148, p. 184-207.

Poole, I., and Cantrill, D., 2001, Fossil woods from Williams Point Beds, Livingston Island, Antarctica: a Late Cretaceous southern high latitude flora: Palaeontology, v. 44, p. 1081-1112.

Pujana, R.R., Marenssib, S.A., and Santillana, S.N., 2015, Fossil woods from the Cross Valley Formation (Paleocene of Western Antarctica): Araucariaceaedominated forests: Review of Palaeobotany and Palynology, v. 222, p. 56-66.

Rai, J., Prasad, M., Prakash, N., Singh, A., Garg, S., Gupta, M., and Pandey, D.K., 2016, Gymnosperm fossil woods from Gangta Bet, eastern Kachchh, western India: Journal of Palaeontological Society of India, v. 61, p. 111-122.

Rajanikanth, A., and Sukh-Dev, A., 1989, The Kota Formation: fossil flora and stratigraphy: Geophytology, v. 19, p. 52-64.

Rao, H.S., 1935, On a sphaerosiderite, containing a new species of Dadoxylon (D. parbeliense) from the Lower Gondwana Coal Measures of India: Records of the Geological Survey of India, v. 69, p. 174-183.

Richter, H.G., Grosser, D., Heinz, I., and Gasson, P.E., 2004, eds, International Association of Wood Anatomists list of microscopic features for softwood identification: IAWA Journal, v. 25, p. 1-70.

Roberts, D. L., Bamford, M., and Millsteed, B., 1997, Permo-Triassic macroplant fossils in the Fort Grey silcrete, East London: South African Journal of Geology, v. 100, p. 157-168.

Rößler, R., Philippe, M., Van Konijnenburg-Van Cittert, J., Mcloughlin, S., Sakala, J., and Zijlstra, G., coordinating authors (and 35 additional authors) 2014, Which name(s) should be used for Araucaria-like fossil wood?Results of a poll: Taxon, v. 63, p. 177-184.

Sah, S.C.D., and Jain, K.P., 1964, Some fossil woods from the Jurassic of Rajmahal Hills, Bihar, India: The Palaeobotanist, v. 12, p. 169-180.

Shukla, V.B., 1938, On a new species of Dadoxylon, D. deccani sp. n. from the Deccan Intertrappean series: Journal Indian Botanical Society, v. 18, p. 35-67. 
Shukla, V. B., 1944, On a new species of Dadoxylon D. resinosum, sp. n. from the Chhindwara District of C.P: Journal Indian Botanical Society, v. 23, p. 83-90.

Singer, P., and Archangelsky, S., 1957, Un nuevo hongo fósil de los bosques petrificados de Santa Cruz. Patagonia: Ameghiniana, v. 1, p. 40-41.

Singhai, L.C., 1958, On a new species of Dadoxylon, D. shuklai sp. n. from Deccan Intertrappean beds of Chhindwara district, Madhya Pradesh: Journal Paleontological Society Indian, v. 3, p. 136-141.

Spalletti, L., Iñiguez Rodriguez, M., and Mazzoni, M., 1982, Edades radiométricas de piroclastitas y volcanitas del Grupo Bahia Laura, Gran Bajo de San Julián, Santa Cruz: Asociación Geológica Argentina, v. 37, p. 483-485.

Spegazzini, C., 1924, Coniferales fósiles patagónicas: Anales Sociedad Científica Argentina, v. 98, p. 125-139.

Stipanicic, P.N., and Reig, O.A., 1957, El "Complejo Porfírico de la Patagonia Extrandina" y su fauna de anuros: Acta Geologica Lilloana, v. 1, p. $185-230$.

Stockey, R.A., 1977, Reproductive biology of the Cerro Cuadrado (Jurassic) fossil conifers: Pararaucaria patagonica: American Journal Botany, v. 64 p. 733-744

Stockey, R.A., 1978, Reproductive biology of Cerro Cuadrado fossil conifers: ontogeny and reproductive strategies in Araucaria mirabilis (Spegazzini) Windhausen: Palaeontographica, v. 166 B, p. 1-15.

Stockey, R.A., and Taylor, T.N., 1978, On the structure and evolutionary relationships of the Cerro Cuadrado fossil conifer seedlings: Botanical Journal of the Linnean Society, v. 76, p. 161-176.

Suryanarayna, K., 1956, Dadoxylon rajmahalense Sahni from the coastal Gondwanas of India: Paleobotanist, v. 4, p. 89-90.

Tidwell, W.D., and Medlyn, D.A., 1993, Conifer wood from the Upper Jurassic of Utah, USA. Part II: Araucarioxylon hoodii sp. n: The Palaeobotanist, v. 42 , p. $70-77$

Torres, T., and Philippe, M., 2002, Nuevas espécies de Agathoxylon y Baieroxylon del Liásico de La Ligua, Chile, y evaluación de antecedentes paleoxilológicos en el Jurásico de América del Sur: Revista Geológica de Chile, v. 29, p. 151-165.

Torres, T., and Rallo, V., 1981, Anatomía de troncos fósiles del Cretácico superior de Pichasca, en el Norte de Chile: Anais II Congreso Latinoamericano Paleontologia, Porto Alegre, Brasil, v. 1, p. 385-397.

Trivedi, B.S., and Srivastava, R., 1989, Gymnospermous woods from Early Tertiary of Chhindwara District, Madhya Pradesh: Phytomorphology, v. 3, p. 61-68.

Vagyani, B.A., and Raju, A.V.V., 1981, A new species of fossil gymnospermous wood Araucarioxylon Kraus from Nandori, Mahashtra State: Biovigyanam, v. 7, p. 11-13.

Vogellehner, D., 1965, Untersuchungen zur Anatomie und Systematik der verkieeselten Hölzer aus dem fränkischen und süd-thüringischen Keuper: Erlanger Geologische Abhandlungen, v. 59, p. 1-76.

Vozenin-Serra, C., and Salard-Cheboldaeff, M., 1992, Les bois Mineralises Permo-Triasiques de Nouvelle Caledonie. Implications Phylogenetique et Paleogeographique: Palaeontographica, v. 225 B, p. 1-25.

White, D., 1908, Flora fóssil das Coal Measures do Brasil: Relatório Final da Comissão dos Estudos das Minas de Carvão de Pedra do Brasil, Rio de Janeiro, v. 1, p. 337-617.

Yadav, R.R., and Bhattacharyya, A, 1996, Climatic significance of growth rings in the Mesozoic woods from India: Palaeobotanist, v. 45, p. 57-63.

Zamuner, A., and Falaschi, P., 2005, Aghatoxylon matildense n. sp., leño araucariáceo del Bosque petrificado del cerro Madre e Hija, Formación La Matilde (Jurásico medio), provincia de Santa Cruz, Argentina: Ameghiniana, v. 42, p. 339-346.

Zamuner, A.B., 1996, Araucarioxylon petriellae n. sp. una posible Glossopteridal de la Formación Melo (Pérmico inferior) Uruguay: Amenghiniana, v. 33 , p. $77-82$

Accepted 26 November 2017 